\title{
20. PALEOECOLOGY AND STRATIGRAPHY OF JURASSIC ABYSSAL FORAMINIFERA IN THE BLAKE-BAHAMA BASIN, DEEP SEA DRILLING PROJECT SITE 534
}

\author{
F. M. Gradstein, Geological Survey of Canada, Bedford Institute of Oceanography, \\ Dartmouth, N. S. B2Y 4A2, Canada
}

\begin{abstract}
At Site 534, Blake-Bahama Basin, 66 brownish to olive green to gray black shale samples from Cores 127 to 70 , of the middle Callovian-Valanginian, contain an assemblage of foraminifers with 36 calcareous taxa in 9 families and 35 agglutinated taxa in 8 families. The average number of taxa per sample is about 5 , with a spread of 0 to 19 and a mode of about 8 . Sample weight $(10-50 \mathrm{~g})$ is not correlated to species diversity and to specimen abundance, which means that a better recovery tool is more rather than bigger samples per core.

R-mode cluster analysis using Jaccard and Dice coefficients of variation on 25 taxa occurring in 5 or more samples show a low level of association. One cluster includes the Kimmeridgian, carbonate-rich environment assemblage with Lenticulina quenstedti, Ophthalmidium carinatum, Neobulimina atlantica n. sp., and Epistomina aff. uhligi. Three clusters comprise stratigraphically persistent taxa of the genera Reophax, Bigenerina, Bathysiphon, Glomospira, Glomospirella, Lenticulina, Rhizammina, Psammosphaera, Dentalina, Lagena, Marginulina, Pseudonodosaria, and Trochammina. Strikingly similar Jurassic assemblages at other Atlantic and Indian oceans sites, which also backtrack to $\sim$ 3-km water depth, show that the Jurassic abyssal fauna principally consists of small-sized agglutinated taxa in 8 or so families, small-sized nodosariids in a dozen or so genera, and variable numbers of epistominids, ophthalminids, spirrilinids, and turrilinids. There is high $(<100)$ species and high $(<50)$ generic diversity, patchy specimen representation, and low species communality between stratigraphically successive samples. The fauna is accompanied by radiolarians, calcispherulids, aptychi, Saccocoma, and largely continues in the Early Cretaceous.

Coeval shallow-marine (neritic) Jurassic assemblages have a much more limited representation of agglutinated taxa. Miliammina, Trocholina, Patellina, Paalzowella, Citharina, Tristix, and large Ammobaculites and Ammomarginulina may be exclusive of this niche, which in general contains larger and more sculptured forms.

At Site 534, 18 taxa group in 3 stratigraphically successive assemblages. The co-occurrence of Conorboides paraspis, Gaudryina heersumensis, Textularia hauesleri, Trocholina nodulosa, and Globuligerina aff. oxfordiana in Core 110, although possibly transported in part, has no oceanic correlative at other sites, which agrees with the interpretation that this Oxfordian assemblage geomagnetically correlates to M-25, not penetrated at other DSDP sites.

The co-occurrence of Lenticulina quenstedti and Epistomina aff. uhligi at DSDP Sites 534, 391, 105, and 367 may be a Kimmeridgian event; it correlates to M-22 to M-19. The co-occurrence of Dorothia praehauteriviana and Lenticulina nodosa at Sites 534,391, 101, 105, 370, and 416 can be used to correlate late Valanginian strata.

Multiple biostratigraphic comparison at Site 534, Cores 127 to 91, shows Oxfordian-Kimmeridgian-Tithonian stage assignments to be 1 to 5 cores apart.
\end{abstract}

\section{INTRODUCTION}

Our knowledge of the Jurassic foraminiferal fauna in abyssal environments is limited and as far as I know confined to assemblages in the Upper Jurassic at DSDP Sites 99, 100, 105, 367, 391, and 416 in the North Atlantic (Luterbacher, 1972; Kuznetsova and Seibold, 1978; Site 391 report, Benson, Sheridan et al., 1978; Sliter, 1980) and Site 261 in the Indian Ocean (Kuznetsova, 1974) (Fig. 1). So-called bathyal assemblages of the Middle and Late Jurassic have been reported from the French Jura and Apennines by Wernli and Septfontaine (1971) and Farinacci (1965). The deep-water fauna consists principally of small-sized nodosariids and small agglutinated taxa belonging to a dozen or less families and variable admixtures of epistominids, opthalmiids, and spirrilinids, frequently accompanied by radiolarians, calcispherulids, aptychi, and Saccocoma. Larger-sized ag-

\footnotetext{
${ }^{1}$ Sheridan, R. E., Gradstein, F. M., et al., Init. Repts. DSDP, 76: Washington (U.S. Govt. Printing Office).
}

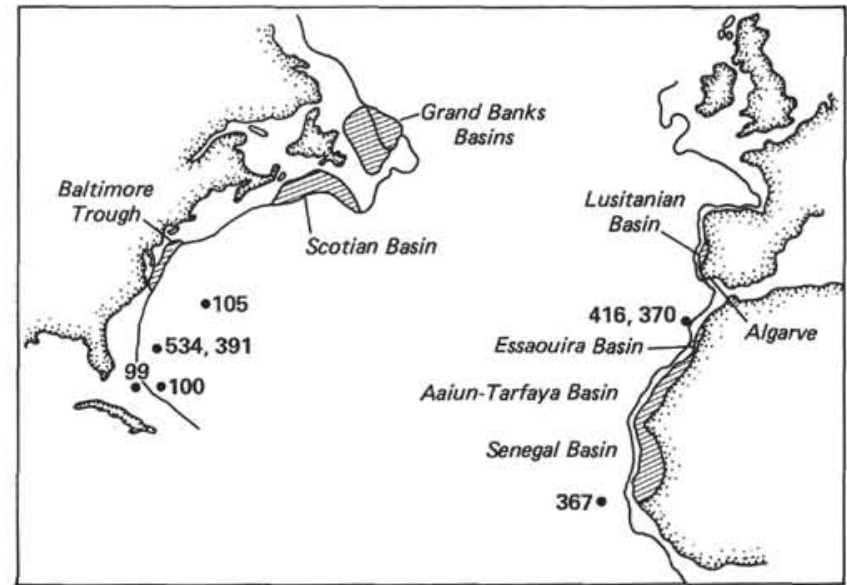

Figure 1. Jurassic "sedimentary wedge" basins, adjacent to the central North Atlantic, and location of Deep Sea Drilling Sites 99, $100,105,367,391,370,416$, and 534 , at which we attempted to core Middle through Late Jurassic sediments laid down on oceanic crust. Site 370 failed to reach Jurassic strata. 
glutinated taxa of Ammobaculites, Lituoliidae, ornamented ostracodes, and echinoderm platelets and spines are absent or known only from microfacies studies of limestones. Questions as to what is exactly the difference between abyssal, bathyal, and neritic Jurassic microfauna and what are the biogeographic and biostratigraphic distributions relative to the early history of the Atlantic-Tethys Ocean remain unanswered. Lack of deep-water sample material suitable for study is an outstanding problem.

During DSDP Leg 76, Middle and Late Jurassic (abyssal) (Figs. 1,2) sediments were cored continuously in Hole 534A in the Blake-Bahama Basin, about $500 \mathrm{~km}$ east of Florida.

In this paper I will examine the Jurassic foraminiferal record in Cores 127 through 91 from a taxonomic, environmental, and stratigraphic point of view. For the sake of continuity, the study has been extended upward to Core 70 in the Early Cretaceous, which also makes possible a better assessment of faunal changes between the Jurassic shaley and Early Cretaceous limestone formations. The chapter is divided into four sectons. First, a general description of the main lithology and microfossil content is presented, with an eye on large-scale variations, turbiditic versus pelagic influences, and so on. Secondly, attention is paid to the taxonomy and composition of the foraminiferal assemblage in relation to other deep- and also shallow-marine Jurassic assemblages, and to the so-called flysch-type agglutinated foraminiferal fauna of the Cretaceous/Tertiary. Next is an attempt to derive paleoecologic information using the age versus depth relationship as a means of estimating Jurassic paleowater depth and R-mode cluster analysis (based on the Dice coefficient of similarity) to demonstrate the degree of association of taxa. In the last section, regional biostratigraphic and chronostratigraphic value of the assemblages is evaluated in the framework of multiple stratigraphy.
One taxon, Neobulimina atlantica $\mathrm{n}$. sp., is new to the literature and described in the Taxonomic Notes at the end of the chapter. Four plates of scanning electron microscope pictures illustrate taxa that occur frequently and/or are stratigraphically useful. It should be stressed that the taxonomy warrants refinement, particularly when more use can be made of comparative collections.

\section{GEOLOGICAL BACKGROUND}

DSDP Site 534 has the geographic coordinates $28^{\circ}$ $20.6^{\prime} \mathrm{N}$ and $75^{\circ} 22.9^{\prime} \mathrm{W}$ (Fig. 3). Water depth is $4974 \mathrm{~m}$, and drilling at the Site reached a total depth of $1666 \mathrm{~m}$; the bottom $30 \mathrm{~m}$ in cores 127 to 130 is oceanic-type basalt (Logothetis, this volume). Using nannofossil, radiolarian, and dinoflagellate stratigraphy, the basal variegated shales are dated as middle Callovian and the Jurassic/Cretaceous boundary is placed between Cores 91 and 92 . This boundary coincides with the top of the grayish red calcareous claystones of the Cat Gap Formation, at the level of seismic Horizon C. This means that the Callovian through Tithonian sedimentary section above basalt is 35 cores or 294 m thick, at 1340 to $1636 \mathrm{~m}$ below the seafloor. Core recovery is $141.1 \mathrm{~m}$ or almost $50 \%$.

Our principal objective at Site 534 was to extend our knowledge of the Jurassic Atlantic Ocean beyond what was known from earlier drilling at several sites during Legs 1, 11, and 44 in the western Atlantic and Legs 41 and 50 in the eastern half, off northwest Africa. Prior to 1980 , at no ocean site had rocks been penetrated much below seismic Horizon C, or older than the Late Jurassic, in the marine magnetic zone closer to the continental margin than M-25. In a nutshell, this history is depicted in Figure 2. Sites 99, 100, and 105 (Leg 11, Hollister, Ewing, et al., 1972) and Site 367 (Leg 41, Lancelot, Seibold, et al., 1978) are located in the magnetic strip of M-25 or landward on the edge of the so-called Jurassic magnetic Quiet Zone (JQZ), which is devoid of high-

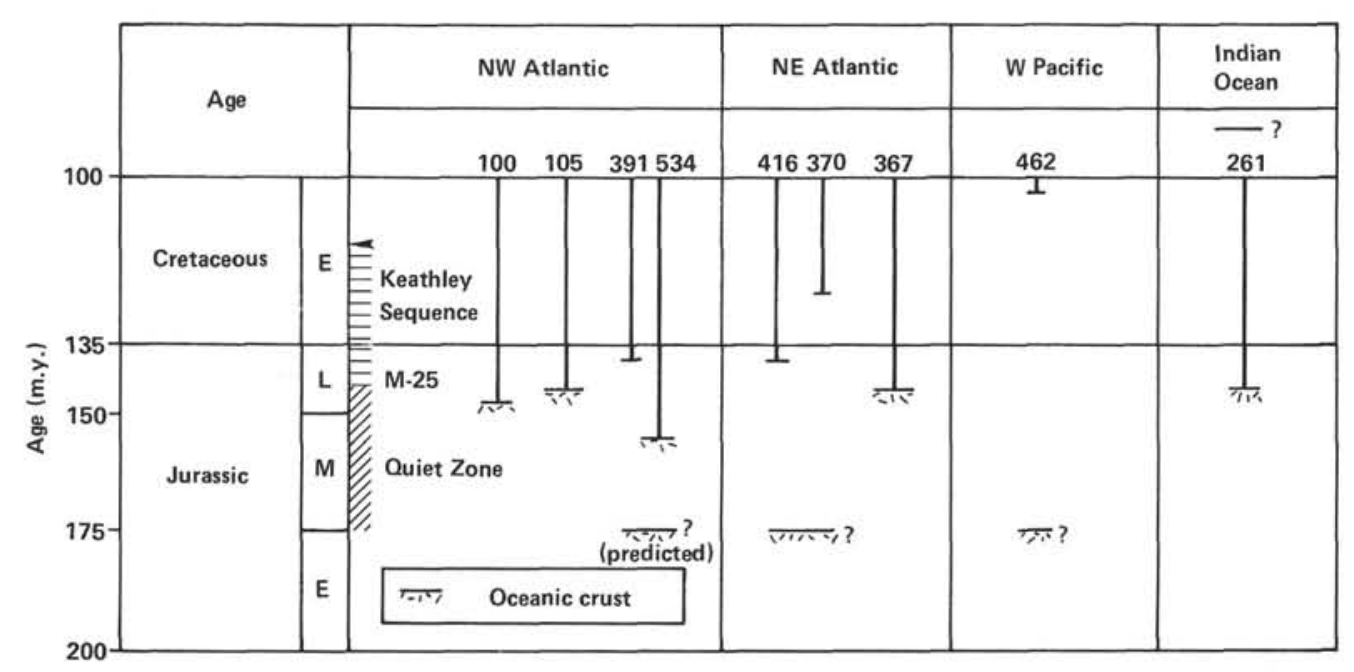

Figure 2. Schematic illustration of the DSDP quest for the oldest oceanic sediments. (The lack of geomagnetic reversals during much of the Jurassic period of ocean history only allows indirect assumptions to be made about the age and timing of opening and early spreading across the oceans' central ridges. Question marks show the inferred stratigraphic positions of basement, which was shown by the Hole 534A basement samples to be one to several stages too old [see text].) 


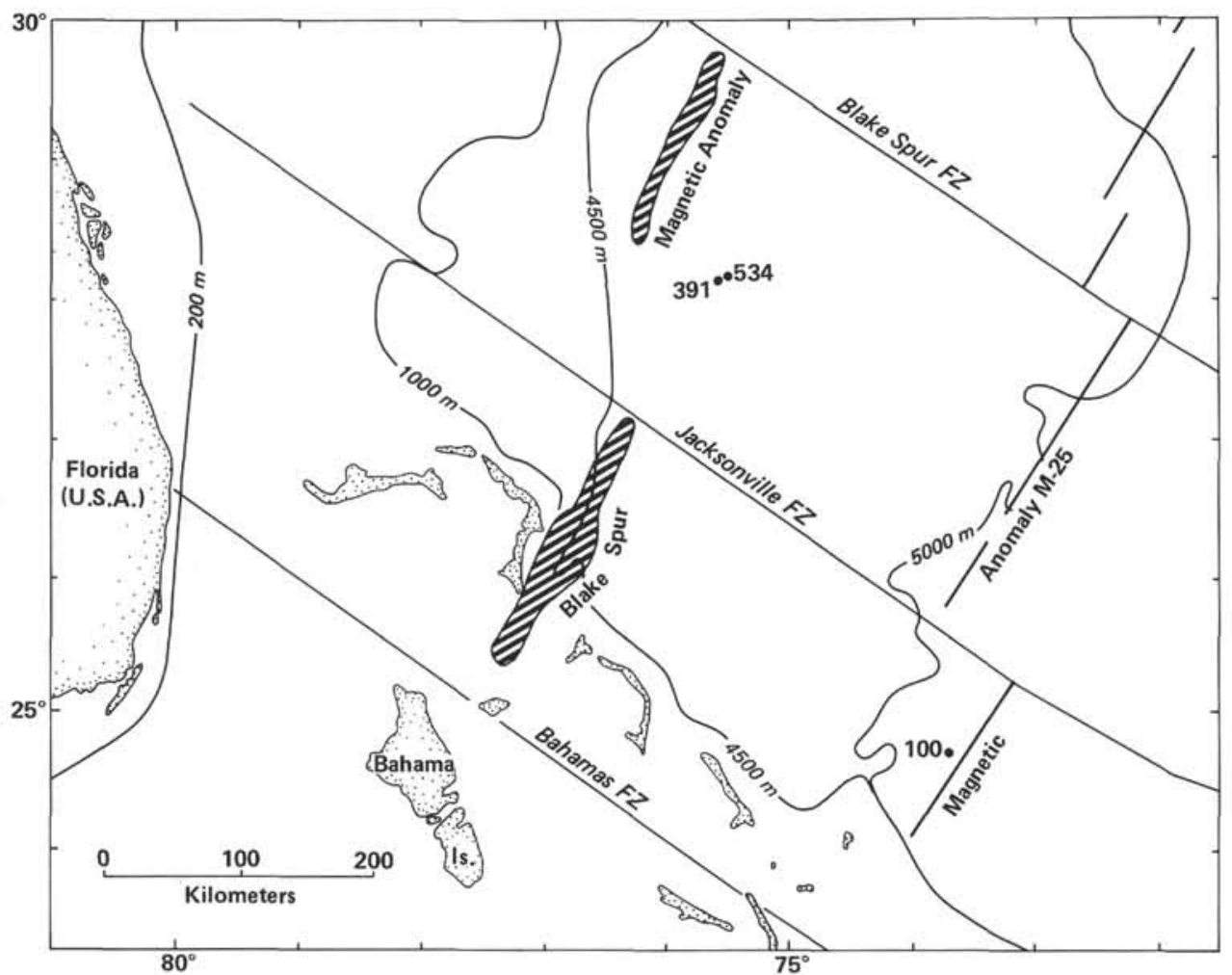

Figure 3. Location of Site 534 on the landward site of the marine Jurassic magnetic Quiet Zone (JQZ). (Present water depth at the Site is $4974 \mathrm{~m}$; total depth cored is $1666.5 \mathrm{~m}$ below the seafloor.)

amplitude magnetic anomalies. At these sites, drilling bottomed in reddish calcareous shale to gray, shaley limestone deposited in the Oxfordian-Kimmeridgian. At both Site 391 (Leg 44, Benson, Sheridan, et al., 1978 ), which is 15 nautical miles southwest of 534, and Site 416 (Leg 50; Lancelot, Winterer, et al., 1980), drilling penetrated to the JQZ region but failed to reach basement or extend much in Jurassic strata. In the $\mathrm{Pa}$ cific, Site 462 (Leg 61, Larson, Schlanger, et al., 1981) failed to reach JQZ rocks. In the Indian Ocean, in front of the western Australian passive margin, at Site 261 (Leg 27, Veevers, J. J., Heirtzler, J. R., 1974), on about M-22, Oxfordian-Kimmeridgian shaley sediments were encountered on the basement.

The larger part of Leg 76 was devoted to Site 534. In order to recover the earliest possible history of seafloor spreading, sedimentation, and biota development, a site was chosen as close as possible to the American continental margin, where basement was estimated to be within drill-string limit $(\sim 7 \mathrm{~km})$. The Site is on a small basement high in a strip of weak magnetic anomaly in the JQZ called M-28 (Bryan et al., 1980). M-25 is $400 \mathrm{~km}$ eastward and the Blake Spur Anomaly $100 \mathrm{~km}$ to the west (Fig. 3). The latter is a basement ridge phenomenon interpretated as an Early-Middle Jurassic spreading center, which subsequently jumped to the present Central Ridge. Site 534 is in the region where the previously nondated seismic reflector D is developed above ocean basement; it pinches out midway between M-27 and M-28 "isochrons" (see Bryan et al., 1980). The continental margin west of the Blake Spur contains the Blake Plateau, a Mesozoic carbonate platform that may have been the source of some of the carbonate-rich turbidites at Site $534,150 \mathrm{~km}$ oceanward on what must have been a Callovian to Tithonian ridge flank or abyssal plain environment.

\section{HOLE 534A, SHELLY MICROFOSSIL ASSEMBLAGE}

A total of 137 claystone samples were studied for shelly microfossils, ranging from Section 534A-127-4 to Sample 534A-70-1, 79-81 cm. The complete listing is in Table 1, which also shows (where available) the dry weight in grams prior to processing. Samples were first fragmented and then boiled for $30 \mathrm{~min}$. in a $35 \% \mathrm{H}_{2} \mathrm{O}_{2}$ and 20 parts Calgon solution, followed by $1 / 2 \mathrm{~min}$. of weak ultrasonic. A stack of 45 - and $63 \mu \mathrm{m}$ sieves were used for screening. Residue splits were picked clean for specimens. Microfossil preservation is adequate for general taxonomic treatment, although in some samples fragmentation of shells has taken place or moderate to total carbonate dissolution.

Table 1 illustrates the stratigraphic distribution of groups of shelly microfossils in relation to the lithology. Ten stratigraphically successive lithologies have been distinguished, which are from top to bottom:

Cores 70 (and above)-76: Blake-Bahama Formation (5b); very finely laminated marly radiolarian, nannofossil chalk, bioturbated chalk and limestone, with minor claystone and siltstone.

Cores 76-84: Blake-Bahama Formation (5c); thinly parallel laminated, marly chalk, bioturbated limestone; thin, graded, calcareous siltstone more heterogenous from core to core than in Subunit 5 b. 


\section{F. M. GRADSTEIN}

Table 1. Micropaleontological and lithological characteristics of Middle-Upper Jurassic and some Lower Cretaceous Hole 534A samples, Cores 127 through 70, Blake-Bahama Basin, western North Atlantic Ocean.

\begin{tabular}{|c|c|c|c|c|c|c|c|c|c|c|c|c|}
\hline \multirow[b]{2}{*}{$\begin{array}{l}\text { Sample } \\
\text { (interval } \\
\text { in } \mathrm{cm} \text { ) }\end{array}$} & \multirow[b]{2}{*}{$\begin{array}{c}\text { Weight } \\
\text { (g) } \\
\text { (prewashed) }\end{array}$} & \multirow[b]{2}{*}{$\begin{array}{l}\text { Percentage of } \\
\text { carbonate in } \\
\text { claystones }\end{array}$} & \multicolumn{2}{|c|}{ Foraminifers } & \multirow[b]{2}{*}{$\begin{array}{l}\text { Radio- } \\
\text { larians }\end{array}$} & \multirow[b]{2}{*}{$\begin{array}{c}\text { Calci- } \\
\text { spherulids }\end{array}$} & \multirow[b]{2}{*}{$\begin{array}{l}\text { Ostra- } \\
\text { codes }\end{array}$} & \multirow[b]{2}{*}{ Aptychi } & \multirow[b]{2}{*}{$\begin{array}{c}\text { Fish } \\
\text { debris }\end{array}$} & \multirow[b]{2}{*}{ Echinoids } & \multirow[b]{2}{*}{$\begin{array}{l}\text { Sponge } \\
\text { spicules }\end{array}$} & \multirow{2}{*}{$\begin{array}{c}\text { Pelecypod } \\
\text { fragments } \\
\text { (?Inocera- } \\
\text { mus) }\end{array}$} \\
\hline & & & $\begin{array}{l}\text { Calcareous } \\
\text { benthic }\end{array}$ & $\begin{array}{l}\text { Aggluti- } \\
\text { nated } \\
\text { benthic }\end{array}$ & & & & & & & & \\
\hline $\begin{array}{l}70-1,79-81 \\
70-3,88-90 \\
70-4,68-870 \\
71-1,26-28 \\
\end{array}$ & $\begin{array}{l}19 \\
22 \\
13\end{array}$ & \multirow{6}{*}{$\begin{array}{l}\text { Range } 5-30 ; \\
\text { average } 18 \% \\
\text { (9 samples) }\end{array}$} & $\begin{array}{l}\mathrm{x} \\
\mathrm{x} \\
y\end{array}$ & $\begin{array}{l}0 \\
0 \\
1 \\
1\end{array}$ & $\begin{array}{l}0 \\
x \\
1 \\
0\end{array}$ & & & & & & & \\
\hline $\begin{array}{l}71-2,109-111 \\
71-4,63-65 \\
72-1,60-62 \\
72-3,100-102\end{array}$ & $\begin{array}{l}20 \\
18\end{array}$ & & $\begin{array}{l}1 \\
0 \\
x\end{array}$ & $\begin{array}{l}0 \\
x\end{array}$ & $\begin{array}{l}\text { Xpy } \\
\text { Opy } \\
\text { X }\end{array}$ & & & & & & & \\
\hline $\begin{array}{l}72-4,32-34 \\
73-1,133-134 \\
73-1,119-121 \\
73-3,47-48 \\
\end{array}$ & $\begin{array}{l}23 \\
37 \\
16\end{array}$ & & I & I & $\begin{array}{l}\text { /py } \\
/ \text { py } \\
\\
\text { py }\end{array}$ & & & & & & & \\
\hline $\begin{array}{l}74-2,62-64 \\
74-3,77-79 \\
74-5,56-58 \\
75-1,44-45 \\
\end{array}$ & $\begin{array}{l}27 \\
26 \\
15\end{array}$ & & & & $\begin{array}{l}0_{\text {py }} \\
\text { py }\end{array}$ & & & & & & & \\
\hline $\begin{array}{l}75-3,39-41 \\
75-4,46-48 \\
76-1,94-86 \\
76-3,15-17\end{array}$ & $\begin{array}{l}26 \\
22\end{array}$ & & & & $\overbrace{\text { py }}$ & & & 1 & & & & 0 \\
\hline $\begin{array}{l}76-6,51-53 \\
77-4,2-4 \\
78-2,78-80 \\
78-3,64-66 \\
\end{array}$ & $\begin{array}{l}31 \\
16\end{array}$ & & $\begin{array}{l}X \\
x\end{array}$ & $x$ & $\begin{array}{l}? \text { py } \\
0 \\
0 \\
x\end{array}$ & 1 & & & & & 1 & \\
\hline $\begin{array}{l}78-4,72-74 \\
79-1,57-59 \\
79-2,64-65 \\
79-3,53-55 \\
\end{array}$ & $\begin{array}{l}18 \\
30 \\
25\end{array}$ & \multirow{12}{*}{$\begin{array}{c}\text { Range } 14-44 \% \\
\text { average } 35 \% \\
\text { (13 samples) }\end{array}$} & & & $\begin{array}{l}0 \\
x \\
0\end{array}$ & & & & & & & \\
\hline $\begin{array}{l}80-3,68-70 \\
80-3,74-75 \\
81-1,58-59 \\
81-4,40-42\end{array}$ & $\begin{array}{l}24 \\
15\end{array}$ & & & & $\begin{array}{l}\text { X } \\
\text { py }\end{array}$ & & & $\begin{array}{l}1 \\
1\end{array}$ & & & & \\
\hline $\begin{array}{l}81-4,46-47 \\
82-1,51-53 \\
82-1,64-66 \\
83-1,19-22 \\
\end{array}$ & $\begin{array}{l}10 \\
18\end{array}$ & & 1 & 1 & 0 & & & , & 1 & & & - ob \\
\hline $\begin{array}{l}83-1,23-24 \\
83-5,63-65 \\
84-2,75-77 \\
84, C C\end{array}$ & $\begin{array}{l}22 \\
12 \\
22 \\
70\end{array}$ & & 1 & & $\begin{array}{l}\text { Xpy } \\
X ? \\
0 \\
\text { py }\end{array}$ & & & & I & & & $\begin{array}{l}1 \\
1\end{array}$ \\
\hline $\begin{array}{l}85-2,44-45 \\
85-3,11-12 \\
86-1,147-148 \\
86-2,101-102 \\
\end{array}$ & $\begin{array}{r}23 \\
8 \\
8 \\
11\end{array}$ & & 1 & 1 & $\begin{array}{l}\mathrm{X} \\
\mathrm{X} \\
\mathrm{X} \\
\mathrm{X}\end{array}$ & & & $\begin{array}{l}1 \\
1\end{array}$ & $\mathrm{X}$ & & & \\
\hline $\begin{array}{l}86-5,16-17 \\
87-1,25-27 \\
87-1,50-51 \\
87-1,81-82 \\
\end{array}$ & 23 & & & & $\begin{array}{l}1 \\
x \\
0 \\
1\end{array}$ & & & & & & & \\
\hline $\begin{array}{l}87-4,68-70 \\
88-1,50-52 \\
88-2,9-10 \\
88-5,94-95 \\
\end{array}$ & $\begin{array}{l}26 \\
20\end{array}$ & & $\begin{array}{l}1 \\
0 \\
x\end{array}$ & $\begin{array}{l}1 \\
0 \\
x\end{array}$ & $\begin{array}{l}x \\
0 \\
0\end{array}$ & & I & $x$ & 0 & & & $x$ \\
\hline $\begin{array}{l}88-5,117-119 \\
89-2,66-67 \\
89-3,52-54 \\
89-3,146-148 \\
\end{array}$ & $\begin{array}{l}25 \\
20\end{array}$ & & $\begin{array}{l}1 \\
1\end{array}$ & 1 & $\begin{array}{l}0 \\
\mathrm{x} \\
\mathrm{x} \\
1\end{array}$ & & & 1 & $\begin{array}{l}0 \\
0\end{array}$ & & & $\begin{array}{l}1 \\
1\end{array}$ \\
\hline $\begin{array}{l}90-1,73-75 \\
90-3,52-53 \\
90-4,32-33 \\
91-1,20-21 \\
\end{array}$ & $\begin{array}{l}39 \\
18 \\
\\
10\end{array}$ & & 1 & l & $\begin{array}{l}x \\
x \\
0\end{array}$ & & & 1 & 0 & & & \\
\hline $\begin{array}{l}91-3,37-38 \\
91-4,109-110 \\
92-2,62-64 \\
92-3,22-23 \\
\end{array}$ & $\begin{array}{l}18 \\
17 \\
\end{array}$ & & $\begin{array}{l}x \\
1 \\
1 \\
1 \\
\end{array}$ & & $\begin{array}{l}\mathrm{X} \\
\mathrm{X} \\
\mathrm{X} \\
\bullet \\
\end{array}$ & & & $\begin{array}{l}1 \\
1 \\
1\end{array}$ & - & & & \\
\hline $\begin{array}{l}92-5,56-57 \\
93-2,45-46 \\
93-2,142-144 \\
93-3,6-7 \\
\end{array}$ & $\begin{array}{l}12 \\
19 \\
20\end{array}$ & & $\begin{array}{l}\mathrm{x} \\
1 \\
\mathrm{x}\end{array}$ & $\begin{array}{l}1 \\
1 \\
x\end{array}$ & 0 & 0 & 1 & $x$ & 1 & & & \\
\hline $\begin{array}{l}94-1,30-32 \\
94-1,140-142 \\
94-2,90-91\end{array}$ & $\begin{array}{l}31 \\
34\end{array}$ & & $\begin{array}{l}x \\
1 \\
0\end{array}$ & $\begin{array}{l}0 \\
X \\
X\end{array}$ & $\begin{array}{l}\mathrm{X} \\
\mathrm{x}\end{array}$ & - & 1 & $\mathrm{x}$ & $\mathrm{x}$ & & & $\mathrm{x}$ \\
\hline
\end{tabular}


Table 1. (Continued).

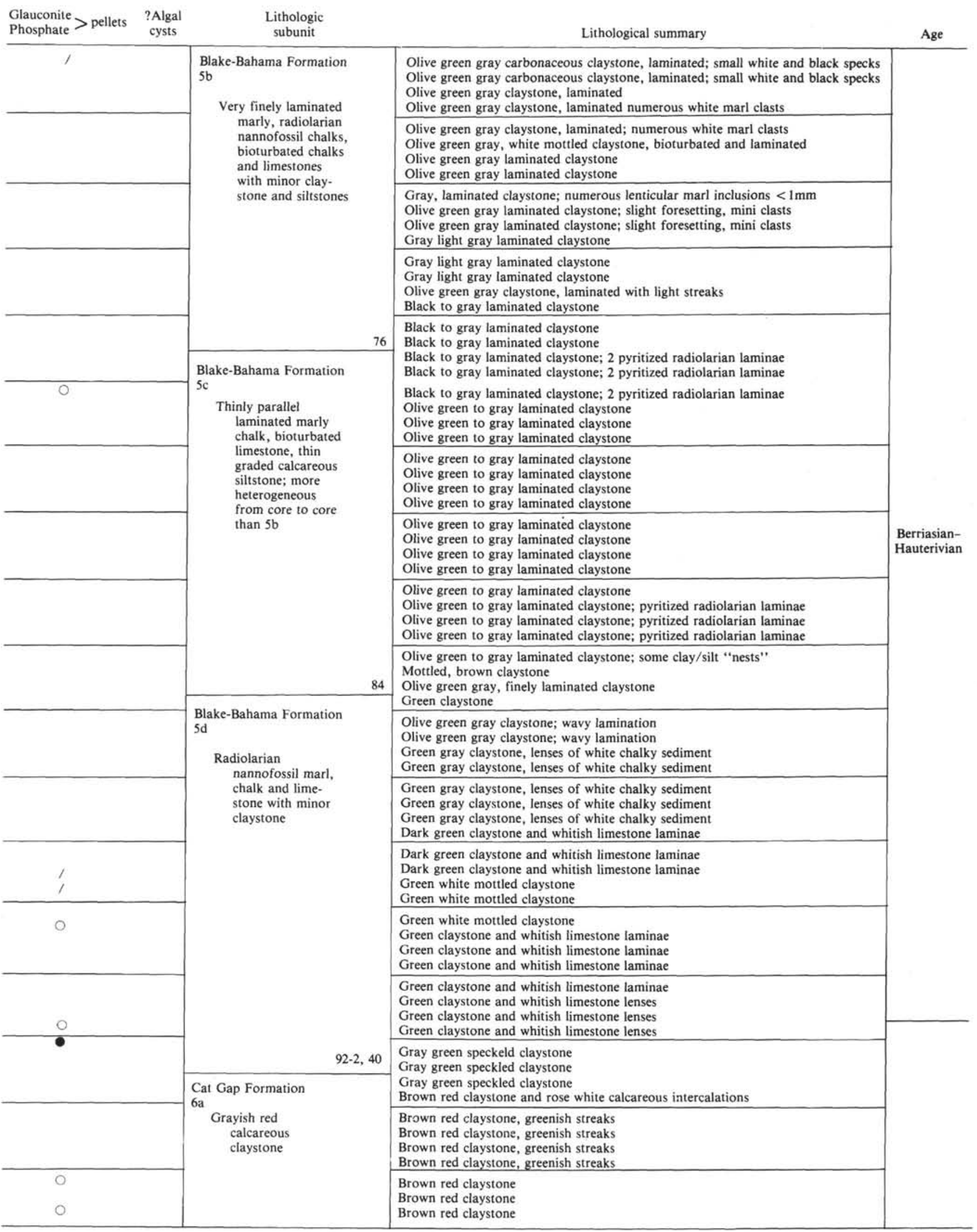




\section{F. M. GRADSTEIN}

Table 1. (Continued).

\begin{tabular}{|c|c|c|c|c|c|c|c|c|c|c|c|c|}
\hline \multirow[b]{2}{*}{$\begin{array}{c}\text { Sample } \\
\text { (interval } \\
\text { in } \mathrm{cm} \text { ) }\end{array}$} & \multirow[b]{2}{*}{$\begin{array}{c}\text { Weight } \\
\text { (g) } \\
\text { (prewashed) }\end{array}$} & \multirow[b]{2}{*}{$\begin{array}{l}\text { Percentage of } \\
\text { carbonate in } \\
\text { claystones }\end{array}$} & \multicolumn{2}{|c|}{ Foraminifers } & \multirow[b]{2}{*}{$\begin{array}{l}\text { Radio- } \\
\text { larians }\end{array}$} & \multirow[b]{2}{*}{$\begin{array}{c}\text { Calci- } \\
\text { spherulids }\end{array}$} & \multirow[b]{2}{*}{$\begin{array}{l}\text { Ostra- } \\
\text { codes }\end{array}$} & \multirow[b]{2}{*}{ Aptychi } & \multirow[b]{2}{*}{$\begin{array}{c}\text { Fish } \\
\text { debris }\end{array}$} & \multirow[b]{2}{*}{ Echinoids } & \multirow[b]{2}{*}{$\begin{array}{l}\text { Sponge } \\
\text { spicules }\end{array}$} & \multirow{2}{*}{$\begin{array}{c}\text { Pelecypod } \\
\text { fragments } \\
\text { (?Inocera- } \\
\text { mus) }\end{array}$} \\
\hline & & & $\begin{array}{c}\text { Calcareous } \\
\text { benthic }\end{array}$ & $\begin{array}{l}\text { Aggluti- } \\
\text { nated } \\
\text { benthic }\end{array}$ & & & & & & & & \\
\hline $94-4,47-48$ & & & 1 & 1 & & & & 1 & & & & \\
\hline $\begin{array}{l}94, C C \\
95-1,36-38 \\
95-1,43-45 \\
95-3,51-53 \\
\end{array}$ & $\begin{array}{l}22 \\
19 \\
\end{array}$ & \multirow{6}{*}{$\begin{array}{l}\text { Range } 7-70 \% \\
\text { average } 30 \%\end{array}$} & $\begin{array}{l}1 \\
1 \\
0\end{array}$ & $\begin{array}{l}\bullet \\
y \\
\mathrm{x} \\
\mathrm{x}\end{array}$ & $\mathrm{x}$ & ' & 1 & & $x$ & & & \\
\hline $\begin{array}{l}96-1,88-89 \\
96-1,89-90 \\
96-3,6-8 \\
97-1,8-9 \\
\end{array}$ & $\begin{array}{l}17 \\
20 \\
26 \\
\end{array}$ & & 1 & $\begin{array}{l}1 \\
1\end{array}$ & 0 & $\begin{array}{l}0 \\
\mathrm{x} \\
\end{array}$ & $\begin{array}{l}1 \\
1 \\
1\end{array}$ & i & & & & $\mathrm{x}$ \\
\hline $\begin{array}{l}99-1,4-6 \\
99-1,38-40 \\
99-3,77-78 \\
100-1,5-6 \\
\end{array}$ & 20 & & $\begin{array}{l}0 \\
x \\
0\end{array}$ & $\begin{array}{l}0 \\
1 \\
0\end{array}$ & I & $\bullet$ & 1 & ' & & & & \\
\hline $\begin{array}{l}100-1,19-20 \\
100-2,6-7 \\
100-4,46-47 \\
101-2,140-142\end{array}$ & $\begin{array}{l}20 \\
18 \\
29 \\
\end{array}$ & & $\begin{array}{l}\mathrm{X} \\
0 \\
0 \\
\end{array}$ & $\begin{array}{l}\mathrm{X} \\
0 \\
0\end{array}$ & & $\bullet$ & 1 & & & & & \\
\hline $\begin{array}{l}101-3,17-18 \\
101-4,93-95 \\
101-6,7-9 \\
102-1,78-79 \\
\end{array}$ & $\begin{array}{l}29 \\
21\end{array}$ & & $\begin{array}{l}1 \\
0 \\
x \\
1\end{array}$ & $\begin{array}{l}x \\
x \\
x \\
y\end{array}$ & I & - & ' & $\begin{array}{l}1 \\
1\end{array}$ & & & & $\mathrm{x}$ \\
\hline $\begin{array}{l}102-2,64-66 \\
102-5,75-77 \\
103-1,107-108 \\
104-1,49-50 \\
\end{array}$ & $\begin{array}{l}27 \\
28 \\
24 \\
\end{array}$ & & $\begin{array}{l}x \\
\vdots \\
1 \\
\end{array}$ & $\begin{array}{l}0 \\
\bullet \\
1\end{array}$ & 0 & & & & & & & \\
\hline $\begin{array}{l}104-1,60-62 \\
104-3,38-39 \\
104-4,33-34 \\
105-1,22-23 \\
\end{array}$ & $\begin{array}{l}12 \\
24 \\
14 \\
\end{array}$ & \multirow[b]{2}{*}{$\begin{array}{l}\text { Range } 17-50 \% \\
\sim 30 \% \text { in marls }\end{array}$} & $\begin{array}{l}1 \\
0 \\
x \\
1\end{array}$ & $\begin{array}{l}x \\
x \\
\bullet \\
\end{array}$ & & ; & ' & ' & & & & ' \\
\hline $\begin{array}{l}105-2,67-68 \\
106-1,52-53 \\
107-2,100-101 \\
108-1,45-47 \\
\end{array}$ & $\begin{array}{l}15 \\
16 \\
35 \\
\end{array}$ & & $\begin{array}{l}1 \\
x \\
x \\
\end{array}$ & $\begin{array}{l}\bullet \\
1 \\
0 \\
x \\
\end{array}$ & & 0 & 1 & & & & & ' \\
\hline $\begin{array}{l}108-1,66-68 \\
110, C C, 15 \\
111-1,17-19 \\
112-1,7-8 \\
\end{array}$ & $\begin{array}{l}12 \\
16\end{array}$ & \multirow{3}{*}{$10-15 \%$} & $\begin{array}{l}x \\
x \\
y\end{array}$ & $\begin{array}{l}0 \\
1\end{array}$ & ? & & 0 & & & & $?$ & \\
\hline $\begin{array}{l}112-1,10-12 \\
112-1,62-64 \\
113-1,24-26 \\
114-1,105-107\end{array}$ & $\begin{array}{l}22 \\
19 \\
18 \\
19 \\
\end{array}$ & & $\begin{array}{l}x \\
1 \\
1\end{array}$ & $\begin{array}{l}x \\
1\end{array}$ & & & I & & & & 1 & 1 \\
\hline $\begin{array}{l}115-1,6-8 \\
115-1,27-28 \\
115-1,33-35 \\
115-1,103-105\end{array}$ & $\begin{array}{l}25 \\
22 \\
22 \\
\end{array}$ & & $\begin{array}{l}\mathrm{x} \\
/ \\
\mathrm{x}\end{array}$ & $\begin{array}{l}1 \\
1\end{array}$ & & & $\mathrm{X}$ & & & & & \\
\hline $\begin{array}{l}116-1,54-55 \\
117-1,12-13 \\
118-1,0-1 \\
119-1,111-112 \\
\end{array}$ & $\begin{array}{l}21 \\
16 \\
14 \\
20 \\
\end{array}$ & \multirow{2}{*}{$\begin{array}{c}\text { Claystones } \\
? 0 \%\end{array}$} & 0 & $x$ & $x$ & ' & & & & & & \\
\hline $\begin{array}{l}120-1,46-47 \\
121-1,0-1 \\
123-1,48-51 \\
123-2,56-58 \\
\end{array}$ & $\begin{array}{l}12 \\
34 \\
30 \\
\end{array}$ & & $\begin{array}{l}1 \\
0\end{array}$ & & $\begin{array}{l}\bullet \\
\mathrm{x} \\
\end{array}$ & & & & & & & \\
\hline $\begin{array}{l}123-3,12-15 \\
124-1,73-75 \\
125-3,60-62 \\
125-5,40-42 \\
\end{array}$ & $\begin{array}{l}37 \\
24 \\
40 \\
39 \\
\end{array}$ & \multirow{4}{*}{$\begin{array}{l}11-30 \% \\
\sim 20 \%\end{array}$} & 1 & ' & $\bullet_{\text {py }}$ & & & & & & & \\
\hline $\begin{array}{l}125-6,13-15 \\
126-1,70-73 \\
126-2,68-70 \\
126-3,120-122 \\
\end{array}$ & $\begin{array}{l}26 \\
36 \\
23 \\
36 \\
\end{array}$ & & - & $\begin{array}{l}\mathrm{X} \\
\bullet\end{array}$ & -py & & & & & & & \\
\hline $\begin{array}{l}126-4,56-58 \\
127-1,59-62 \\
127-3,40-42 \\
127-4,13-15 \\
\end{array}$ & $\begin{array}{l}28 \\
51 \\
50 \\
40 \\
\end{array}$ & & $\begin{array}{l}\bullet \\
1 \\
x \\
\end{array}$ & $\begin{array}{l}- \\
\mathrm{x} \\
\end{array}$ & & & & & & & & \\
\hline $127,7-9$ & 39 & & / & & & & & & & & & \\
\hline
\end{tabular}

Note: The lithostratigraphic units and broad ages are as shown in the Site 534 report (this volume). For discussion see text. $=>50$ specimens, $\bigcirc=21-50$ specimens, $X=6-20$ specimens, and $/=1-5$ specimens; $a b=$ abraded, $p y=$ pyritized. 
Table 1. (Continued).

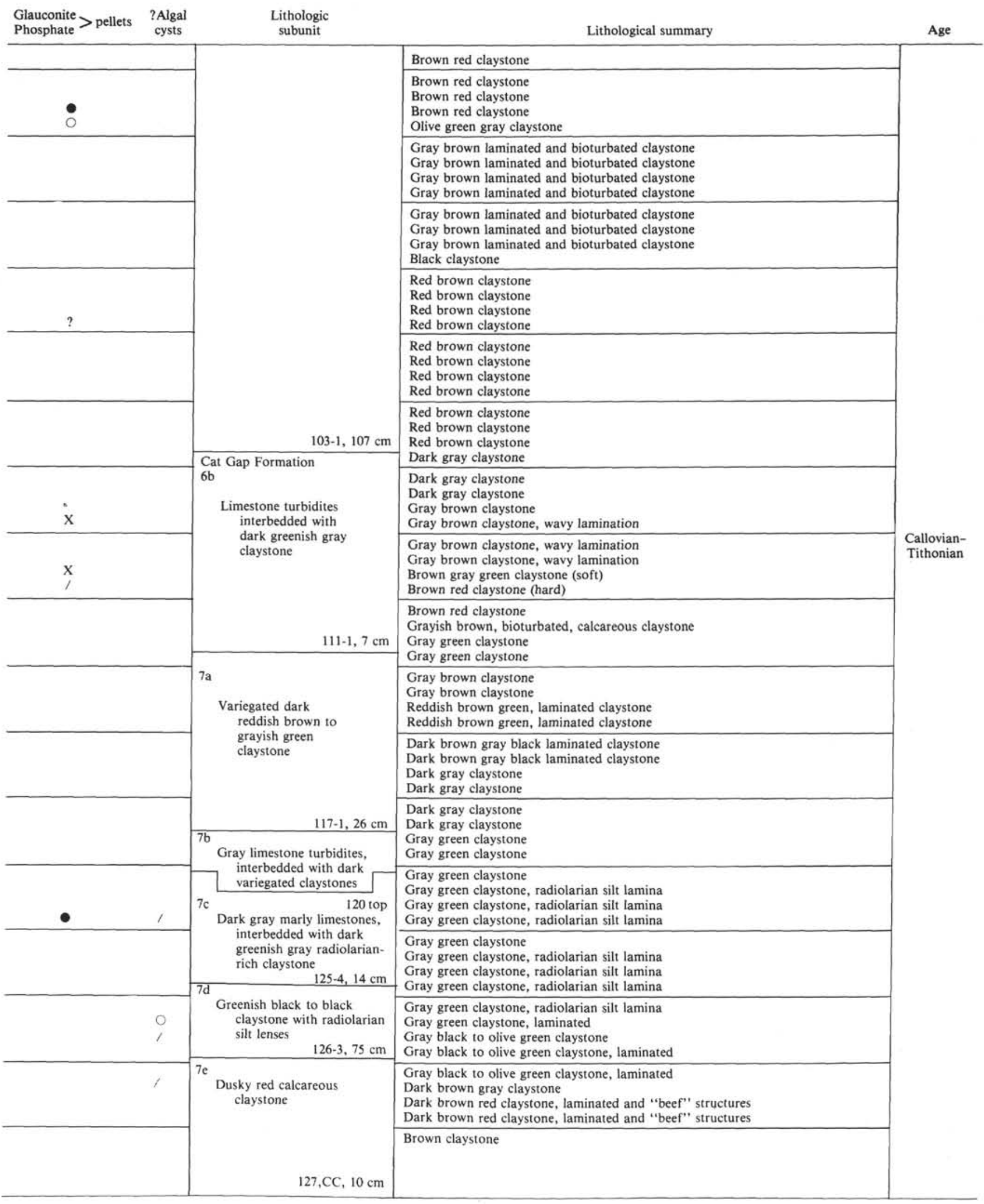


Core 84 to Core 92, Section 2: Blake-Bahama Formation (5d); radiolarian-nannofossil marl, chalk, and limestone, with minor claystone.

Core 92, Section 2 to Core 103, Section 1: Cat Gap Formation (6a); grayish red calcareous claystone.

Core 103, Section 1 to Core 111, Section 1: Cat Gap Formation (6b); limestone turbidites, interbedded with dark greenish gray claystone.

Core 111, Section 1 to Core 117, Section 1: Unnamed unit (7a); variegated, dark reddish brown to grayish green claystone.

Core 117, Section 1 to Core 120 (top): Unnamed unit (7b); gray limestone turbidites, interbedded with dark, variegated claystones. Ogg et al. (this volume) include Subunits 7a and b in the Cat Gap Formation.

Core 120 (top) to Core 125, Section 4: Unnamed unit (7c); dark gray, marly limestones, interbedded with dark, greenish gray radiolarian-rich claystone.

Core 125, Section 4 to Core 126, Section 3: Unnamed unit (7d); greenish black to black claystone with radiolarian silt lenses.

Core 126, Section 3 to Sample 127,CC: Unnamed unit (7e); dusky red, calcareous claystone.

Based on the multiple biostratigraphy shown in Figure 9, the unnamed unit is Callovian-Oxfordian, the Cat Gap Formation essentially Kimmeridgian-Tithonian, and the Blake-Bahama Formation samples Berriasian-Valanginian. Calcispherulids are essentially confined to the upper grayish red calcareous claystone subunit (6a) of the upper Cat Gap Formation (Tithonian). Interestingly, this is the interval in which radiolarians, either pyritized or filled by chalcedony or calcite spar, are largely absent. Radiolarians are often abundant in the unnamed unit and particularly in the Blake-Bahama claystones. This pattern of exclusion may have some regional significance and may be related to productivity in the upper water column. Ostracodes are rare and scattered (see Oertli, this volume); aptychi are more frequent in the Tithonian-Berriasian interval, particularly in the upper Cat Gap Formation, where the carbonate percentage is highest $(50-70 \%)$. The higher aptychi concentrations in Cores 94, 92, and 87 may indicate the interval with the lowest sedimentation rate. The frequency distribution in the next four columns in Table 1 on fish debris, echinoderms, sponge spicules, and pelecypods (?Inoceramus) prisms should be mostly related to downto-basin transport activity. There is no relation to the units where more sediment mass transport beds have been noticed during core examination.

Foraminifera, both calcareous and agglutinated, are most consistently present, with diversified and specimen-rich assemblages in the reddish claystones of Subunits 7e (Callovian) and 6a (Cat Gap Formation, Tithonian). Ogg et al. (this volume), advance the idea that the red color is to some extent related to an increase of $\mathrm{Fe}$ over organic matter and to a slower sedimentation rate. It is not immediately apparent what the effect of these agents would be on foraminiferal bottom dwellers, but a slower sedimentation rate will produce less dilution of biomass in time and increase the number and type of shells per unit volume of sediment.
Because we expect that the sedimentation rate fluctuates considerably from bed to bed or between lithologic units, the size and weight of the samples taken would presumable not much influence the number of microfossil shells and its diversity. Of course, if sample size varies more than the sedimentation rate, the effect will decline, but in my samples, which vary a factor of 2-4 in size, the reasoning holds. I correlated the four frequency classes of foraminifers (rare, common, frequent, and abundant) and the number of taxa per sample to the weight of the sample (Fig. 4). Where there was an insample difference between agglutinated and calcareous frequencies, the larger of the two classes per sample was used. Spearmans rank correlation suggests very low likelihood of correlation $(R=-0.04282)$ and so does the Kendall rank correlation test. Of course, either of the agglutinated or calcareous frequencies might be positively correlated to sample size, but such is not the case either. Changes in sedimentation rate, probably coupled with productivity and dissolution rates, produce abundance and diversity changes that are not offset by the size of the sample. Denser sampling frequency per core or formation is a more effective recovery tool than larger sample size at a few discrete levels.

There are no carbonate content values at the exact level of the samples, but inspection of the generalized carbonate content $\log$ in Table 1 suggests that there is an increase of foraminiferal shells in intervals with more carbonate. Obviously, fluctuations of the level of the carbonate compensation depth (CCD) and of the lysocline have influenced the living and fossil record. Very dark-colored shales and carbonate-poor or carbonatefree shales are virtually devoid of taxa, even agglutinated ones, as in Sub units $7 \mathrm{c}$ and d. Reducing bottom conditions during periods of high organic influx or a shallow CCD will reduce the record.

Using the shelly microfossil and macrofossil debris record together, some evidence for distinctive stratigraphic intervals with increased reworking can be mapped. A number of samples contain a sorted, very small-sized ( $\geq 60 \mu \mathrm{m})$, and often abraded assemblage, as in Sections 534A-112-1, 534A-115-1, 534A-123-1, and 534A-126-3 and -4 . This may be a distal turbidite component, which in the case of Core 123 is almost wholly calcareous. Composition of the tiny-sized assemblage is not noticeably different from normal-sized assemblages in adjacent samples, which suggests transportation of deeper-water meiofauna. In Cores 110 and 94 some specimens of unique taxa occur, which more likely are shallow-marine contaminants like Trocholina, Conorbina, Conorboides, and even the tiny globigerinids. Further evidence for reworking and transportation comes from an abundance of abraded calcareous debris or abraded tests in Sections 534A-89-5, 534A-88-2, and 534A-82-1.

Summing up the evidence, reworking may thus particularly occur in Cores 127 to 123 (Callovian), 115 to 110 (Oxfordian), and 89 to 82 (late Berriasian). Further studies are necessary to determine if this reworking is part of a more systematic basin record, which could be linked to periodic changes in sedimentary style. 

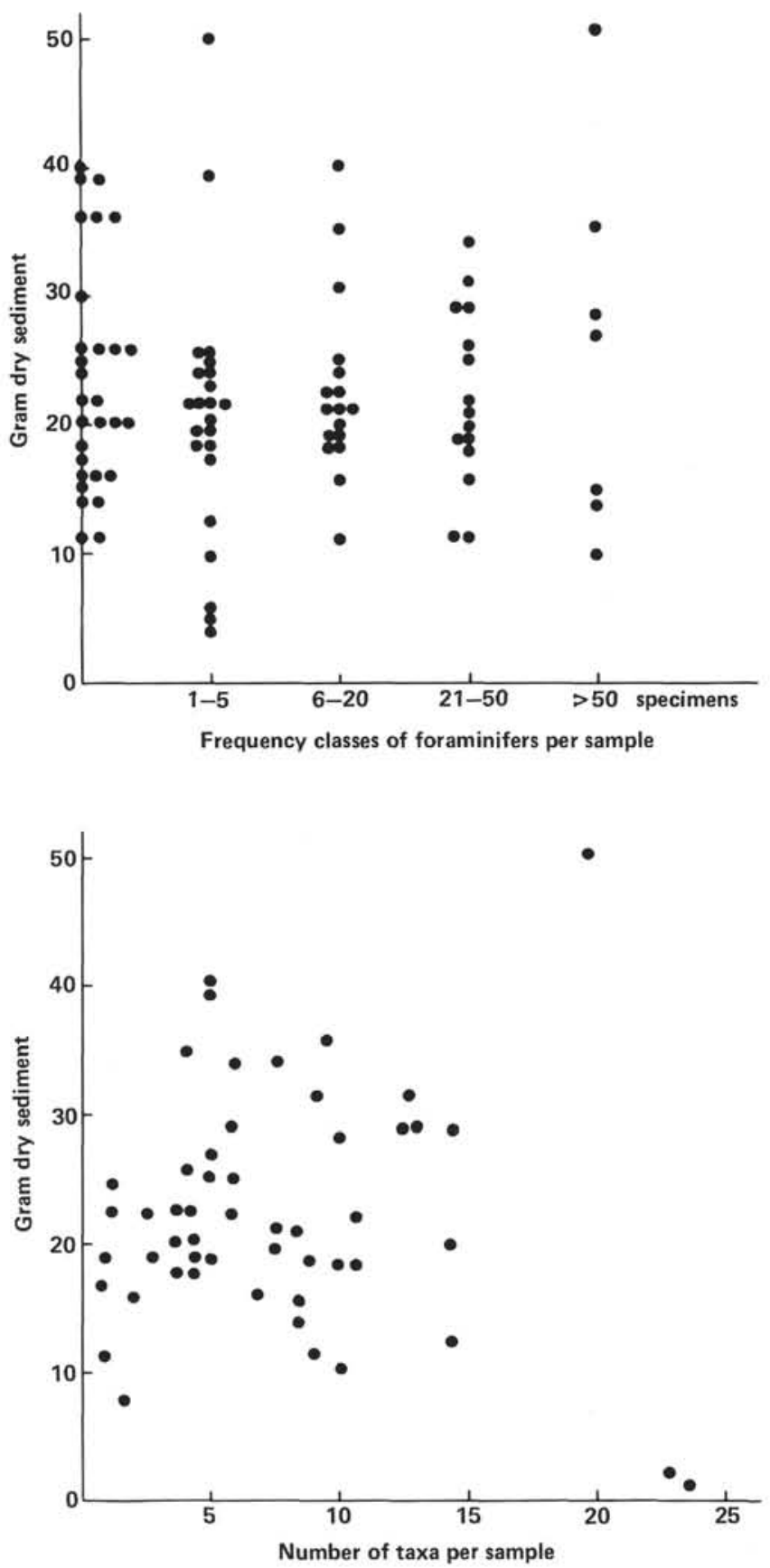

Figure 4. There is no positive correlation at a reasonable level of significance (using Kendall or Spearman rank correlation tests) of the frequency of foraminifer specimens per grams of sediment and of the number of taxa per grams of sediment. (The number of samples is 66 , Cores $534 \mathrm{~A}-70-127$, sample size varying from $10-50$ grams. This probably means that the sedimentation rate and dissolution rate exert more influence on the foraminiferal number and diversity ("biomass") than the five-fold difference in sample size. More closely spaced sampling appears a more effective tool for recovery than larger-sized samples.)

\section{TAXONOMY}

The taxonomy used is conservative, which means that I have lumped specimens showing evidence of gradational morphologic features. The presence in the litera- ture of different names for only slightly different morphologies and the fact that only one-third or so of all taxa occurs in any number of specimens, which are quite small (often $\geq 150 \mu \mathrm{m}$ ) and of moderate preservation, make detailed taxonomy a difficult undertaking. Also, many taxa vary slightly from the well-established morphologies (of shallow-marine environments) but not enough to warrant special taxonomic treatment. A few comments are added in the Taxonomic Notes on selected taxa.

Beside the Catalogue of Foraminifera (Ellis, Messina, et al., 1940-1982) and my own collections, use was made of the following references: Bartenstein and Brand (1951), Lutze (1960), Wall (1960), Oesterle (1968), Ohm (1967), Wernli (1971), Luterbacher (1972), Bartenstein (1974), Kuznetsova (1974), Bielecka and Geroch (1977), Kuznetsova and Seibold (1978), Sliter (1980), Gradstein and Berggren (1981) and Barnard and Shipp (1981). Specimens of Neobulimina atlantica n. sp. (Plate 3, Figs. 1-12) were studied by S. Geroch (Krakow), H. P. Luterbacher (Tübingen), I. Premoli Silva (Milano), W. V. Sliter (Washington), and P. Ascoli (Dartmouth, N. S.) (personal communications, 1980-81). None of these colleagues were aware of a comparative record of such a stubby Neobulimina taxa.

Special attention was given to Jurassic planktonics, but only 12 specimens were isolated-in two samples from 534A-110,CC. The test size of $60 \mu \mathrm{m}$ makes systematic identification tentative, compounded by encrustation of coccoliths, which, according to S. Honjo (Woods Hole) (personal communication, 1981), may have happened as a result of ingestion by larger animals in the food chain. Deposition of these tiny specimens thus may have occurred as part of faecal pellets sedimentation, at a time when planktonic foraminifers were also present in the Jurassic Tethys ocean (Oxfordian), rather than scattered in the marginal Tethys waters or bordering epicontinental seas (Bajocian through Oxfordian-Kimmeridgian). Alternatively, the planktonics, as suggested in the previous section, may be a shallow-marine contaminant. Jurassic planktonic taxonomy leaves much to be desired, but rather than running ahead of studies in progress, I have preferred to match more or less coeval records. Two types are present in the relevant literature, a more globose, trochospiral form with an arched aperture, "Globigerina" helvetojurassica Haeusler and an often low-spired (tiny) form with a virguline or arched aperture, Globuligerina oxfordiana (Grigelis). The Sample 110,CC specimens match the latter better than the former (Plate 2, Figs. 1-10).

The total foraminiferal assemblage in Cores 127 through 70 of Hole 534A consists of at least 36 calcareous taxa in nine(?) families and at least 35 agglutinated taxa in eight families. The 36 calcareous forms belong in 19 genera, whereas there are at least 23 genera of agglutinated foraminifers. The complete taxonomic listing follows. The number of specimens in the samples is indicated in frequency classes: ra (rare) $=1$ to 5 specimens, co (common) $=6$ to 20 specimens, and fr (frequent) $\geq$ 21 specimens; the number indicates the amount of samples in which the taxon was found (maximally 66). 


\section{AGGLUTINATED BENTHIC FORAMINIFERA}

\begin{tabular}{|c|c|c|}
\hline \multirow{2}{*}{\multicolumn{3}{|c|}{ Astrorhizidae }} \\
\hline & & \\
\hline Rhizammina sp. & ra-fr & 24 \\
\hline Rhabdammina sp. & ra-co & 2 \\
\hline Bathysiphon discreta (Brady) & ra-co & 5 \\
\hline Bathysiphon sp. & ra & 1 \\
\hline $\begin{array}{l}\text { Hyperammina sp. } 2 \text { Bartenstein } \\
\text { (1974) }\end{array}$ & $\mathrm{ra}$ & 1 \\
\hline Hippocrepina sp. & ra-fr & 3 \\
\hline \multicolumn{3}{|l|}{ Saccamminidae } \\
\hline Psammosphaera sp. & ra-fr & 9 \\
\hline \multicolumn{3}{|l|}{ Ammodiscidae } \\
\hline Ammodiscus sp. & ra & 5 \\
\hline Glomospirella gaultina (Berthelin) & ra-fr & 36 \\
\hline $\begin{array}{l}\text { Glomospira charoides (Jones and } \\
\text { Parker) }\end{array}$ & ra-fr & 10 \\
\hline $\begin{array}{l}\text { Glomospira gordialis (Jones and } \\
\text { Parker) }\end{array}$ & ra-fr & 5 \\
\hline Glomospira irregularis (Grzybowski) & ra & 1 \\
\hline Lituotuba sp. & ra & 2 \\
\hline \multicolumn{3}{|l|}{ Hormosinidae } \\
\hline Hormosina sp. & ra & 1 \\
\hline Reophax aff. horridus (Schwager) & ra & 1 \\
\hline Reophax helveticus (Haeusler) & ra-co & 9 \\
\hline Reophax sp. & ra-co & 9 \\
\hline \multicolumn{3}{|l|}{ Lituolidae } \\
\hline Halophragmium aequale (Roemer) & ra & 1 \\
\hline $\begin{array}{l}\text { Haplophragmium inconstans } \\
\text { Bartenstein and Brand }\end{array}$ & ra-co & 2 \\
\hline Haplophragmoides sp. & ra & 1 \\
\hline Haplophragmium sp. & ra & 1 \\
\hline \multicolumn{3}{|l|}{ Textulariidae } \\
\hline $\begin{array}{l}\text { Spiroplectammina helvetojurassica } \\
\text { Kubler and Zwingli }\end{array}$ & ra & 1 \\
\hline $\begin{array}{l}\text { Textularia haeusleri Kaptarenko and } \\
\text { Chernoussova }\end{array}$ & $\mathrm{ra}$ & 3 \\
\hline Textularia sp. & ra & 1 \\
\hline Bigenerina jurassica (Haeusler) & ra-co & 5 \\
\hline Bigenerina arcuata Haeusler & ra-co & 3 \\
\hline \multicolumn{3}{|l|}{ Trochamminidae } \\
\hline $\begin{array}{l}\text { Trochammina globigeriniformis } \\
\text { (Parker and Jones) }\end{array}$ & ra & 3 \\
\hline $\begin{array}{l}\text { Trochamminoides pygmaeus } \\
\text { (Haeusler) }\end{array}$ & ra & 5 \\
\hline $\begin{array}{l}\text { Trochamminoides hyalinus } \\
\text { (Haeusler) }\end{array}$ & ra-co & 4 \\
\hline Trochammina quinqueloba Geroch & ra & 4 \\
\hline $\begin{array}{l}\text { Trochammina(?) deformis Grzy- } \\
\text { bowski }\end{array}$ & ra-co & 5 \\
\hline Trochammina sp. & ra-co & 3 \\
\hline \multicolumn{3}{|l|}{ Ataxophragmiidae } \\
\hline $\begin{array}{l}\text { Dorothia praehauteriviana Dieni } \\
\text { and Massari }\end{array}$ & ra-co & 2 \\
\hline ?Dorothia sp. & ra & 1 \\
\hline Gaudryina heersumensis Lutze & ra & 1 \\
\hline Karreriella sp. & ra & 5 \\
\hline Verneuillina sp. & ra & 1 \\
\hline
\end{tabular}

\section{CALCAREOUS BENTHIC FORAMINIFERA}

\section{Nodosariidae}

Lenticulina quenstedti (Guembel)

Lenticulina (Darbyella) muensteri (Roemer)

Lenticulina nodosa (Reuss)

Lenticulina aff. reticulata (Schwager)

Lenticulina spp.

Dentalina communis (d'Orbigny)

Dentalina incerta Terquem

Dentalina spp.

Pseudonodosaria humilis (Roemer)

Pseudonodosaria spp.

Nodosaria jurassica Guembel
Nodosaria aff. prima d'Orbigny

Nodosaria spp.

Frondicularia nikitini Uhlig

Frondicularia franconica Guembel

Frondicularia sp.

Oolina sp.

Palmula subparallela (Wisniowski)

Lingulina sp.

Marginulina aff. major(Bornemann)

Marginulina spp.

Ramulina spandeli Paalzow

Saracenaria sp.

Lagena laevis (Montagu)

Lagena sp.

Polymorphinidae

Guttulina aff. pygmaea (Schwager)

Turrilinidae

Neobulimina atlantica $\mathrm{n}$. sp. $\quad \mathrm{ra}-\mathrm{fr} 7$

Anomalinidae

?Gavelinella sp.

Discorbidae

Conorbina sp.

Ceratobuliminidae

Epistomina aff. uhligi Mjatliuk

Conorboides paraspis (Schwager)

Involutinidae

Trocholina nodulosa Seibold \& $\quad$ ra Seibold

Trocholina transversarii Paalzow

Nubeculariidae

Ophthalmidium carinatum Kubler and Zwingli

Ophthalmidium milioliniformis (Paalzow)

Ophthalmidium sp.

Spirrilinidae

Spirrilina sp.

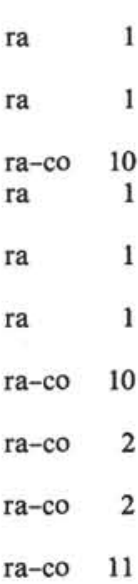

PLANKTONIC FORAMINIFERA

Globuligerina aff. oxfordiana ra 2 (Grigelis)

It can be seen from this list that the assemblage is composed of a few more common species and many more rare ones. The more common ones include several simple agglutinated taxa, one or two nodosariids, Neobulimina, and Ophthalmidium.

\section{PALEOECOLOGY}

The fact that Hole 534A penetrated "basement" of an oceanic-type basalt allows the use of backtracking (Sclater et al., 1977) as a means to estimate the paleobathymetric trends through time. The excercise is performed by Sheridan (this volume) and establishes that Site 534 probably started in the Callovian at an average mid-ridge depth of $2.7 \mathrm{~km}$ and had slowly sank to about $3.3 \mathrm{~km}$ in the Berriasian. This depth estimate situates the Site 534 seafloor well in the abyssal realm, and we shall consider this factor in further discussion.

An appraisal of the Jurassic assemblage in Cores 127 to 70 , relative to other ones of similar or dissimilar age and environmental setting, has to take into account the effects of redeposition and stratigraphic bias. It then becomes more meaningful to consider the observed assemblage to reflect an in situ fauna.

Evidence for reworking was discussed earlier and includes the specimens in Core 110 of Trocholina spp., Conorbina, Conorboides, and possibly Globuligerina. The specimens may be contaminants from neritic(?) environments on the Blake or Bahama Plateaus, westward. 
There is also evidence for reworking in Cores 127 to 123,115 to 110 , and 89 to 82 (see the section on shelly microfossil assemblage), but with the exception of the few specimens in Core 110, there appears to be no appreciable difference in composition between samples inside and outside these cored intervals. Most of the reworking probably amounted to local transportation into the deepest part of the sedimentary basin.

A stratigraphically unique, but probably in situ assemblage occurs in Cores 105 through 95, Kimmeridgian-Tithonian, with persistent and common specimens of Neobulimina atlantica n. sp., Epistomina aff. uhligi, Lenticulina quenstedti, and Ophthalmidium carinatum (see the Fig. 5 dendrogram). I consider this assemblage a response to the carbonate-richer episode when the reddish calcareous claystone of the upper Cat Gap Formation (Subunit 6a) was deposited. At this time the CCD had dropped considerably, and the seafloor was probably close to the aragonite compensation depth (ACD).

Other stratigraphic trends do not involve (groups of) taxa that occur in appreciable number, except for the arrival of Dorothia praehauteriviana, at the top of the interval studied. This is an in situ form, common to Neocomian oceanic sites.

Prior listing of all taxa shows that the calcareous assemblage is made up of Nodosariidae, 25 species in 12 genera, and the odd taxon in the Polymorphinidae, Turrilinidae (Neobulimina), Ceratobulimindae (Epistomi$n a$ ), and Nubeculariidae and Spirrilinidae. Few taxa occur with any number of specimens and only about onethird of all taxa occur in more than six $(10 \%)$ of the samples, including Lingulina, Lenticulina, Lagena, Spirillina, Epistomina, Ophthalmidium, and Neobulimina .

There are 16 taxa that occur in at least seven or more samples and that are not exclusively rare, including (in order of descending stratigraphic persistency):

$\begin{array}{lr}\text { Glomospirella gaultina } & \text { in } 36 \\ \text { Rhizammina } \text { sp. } & 24 \\ \text { Dentalina communis } & 14 \\ \text { Lenticulina } \text { spp. } & 13 \\ \text { Lingulina } \text { sp. } & 12 \\ \text { Lagena laevis } & 11 \\ \text { Spirillina sp. } & 11 \\ \text { Glomospira charoides } & 10 \\ \text { Epistomina } \text { aff. } \text { uhligi } & 10 \\ \text { Ophthalmidium } \text { carinatum } & 10 \\ \text { Reophax helveticus } & 9 \\ \text { Reophax sp. } & 9 \\ \text { Psammosphaera } \text { sp. } & 9 \\ \text { Neobulimina atlantica } \mathrm{n} . \mathrm{sp} . & 7 \\ \text { Pseudonodosaria humilis } & 7 \\ \text { Lenticulina quenstedti } & 7\end{array}$

The average number of taxa per sample is about five, with a spread of 0 to 19 , and a mode of about eight.

In order to aid with the delineation of specific groups of taxa that can be of paleoecological (or stratigraphical) significance in the stratigraphically successive 66 samples, the data were subjected to R-mode cluster analysis. The method used is based on a computer program developed by G. Bonham-Carter (1967). The coefficients of variation used include the Jaccard $C / N_{1}+$
$N_{2}-C$ and Dice $2 C / N_{1}+N_{2}$ coefficients, in which $C=$ the number of samples in which taxon $\mathrm{A}$ and $\mathrm{B}$ co-occur; $N_{1}=$ the number of samples with taxon $A$, and $\mathrm{N}_{2}=$ the number of samples with taxon B. The Dice coefficient emphasizes communality, which in the patchy Hole 534A data leads to slightly better clustering than the Jaccard coefficient. The occurrences of A and B were entered in three frequency classes: rare $=1$ to 5 specimens; common $=6$ to 20 specimens, and frequent $\geq 21$ specimens. The final clustering is affected both by the degree of association and by the relative frequency of taxa. In order to arrive at meaningful answers only taxa were entered that occur in five or more samples. This culling of the data reduces the assemblage from about 70 to 25 (!) species. The R-mode dendrogram, using the Dice coefficient weighted-pair group method, is shown in Figure 5.

The degree of association is relatively low. More common co-occurrences include these "clusters":

1) Reophax helveticus Bigenerina jurassica Reophax sp.

2) Glomospirella gaultina Lenticulina spp. Rhizammina sp.

3) Dentalina communis Lagena laevis

4) Lenticulina quenstedti Ophthalmidium carinatum Neobulimina altantica $\mathrm{n}$. $\mathrm{sp}$. Epistomina aff. uhligi

The analysis confirms the so-called "Kimmeridgian carbonate richer environment" assemblage with Neobulimina atlantica n. sp., and so on, in "cluster" no. 4. The other three "clusters" are rather arbitrarily limited to the tightest-linking elements of what appear to be two larger "clusters" of stratigraphically persistent taxa. The most striking elements include those in cluster no. 2, which consists of the three stratigraphically most common taxa. It is not obvious what the reason for correlating might be, but further research may shed light on these communality relationships. One is probably justified in arguing that species of the genera Reophax, Bigerina, Bathysiphon, Glomospira, Glomospirella, Lenticulina, Rhizammina, Psammosphaera, Dentalina, Lagena, Marginulina, Pseudonodosaria, and Trochammi$n a$ are significant and unspecialized elements of Jurassic abyssal fauna.

It is instructive to make a comparison to other known abyssal Jurassicc assemblages. Table 2 lists all oceanic (Upper) Jurassic micropaleontological sites. Paleo-water depth estimates using backtracking do not indicate shallower than average depth for the basal sediments on ocean crust, and the water depth ranges from $2.7 \mathrm{~km}$ for the oldest to $3.3 \mathrm{~km}$ for the younger deposits.

Excellent reports on these sites by the shipboard biostratigraphers allow insight into the compositional variation, which is expressed in Table 3 . In the absence of comparative collections only a minor effort was made to standardize taxonomic nomenclature. There is a striking similarity in overall composition to the Indian Ocean 

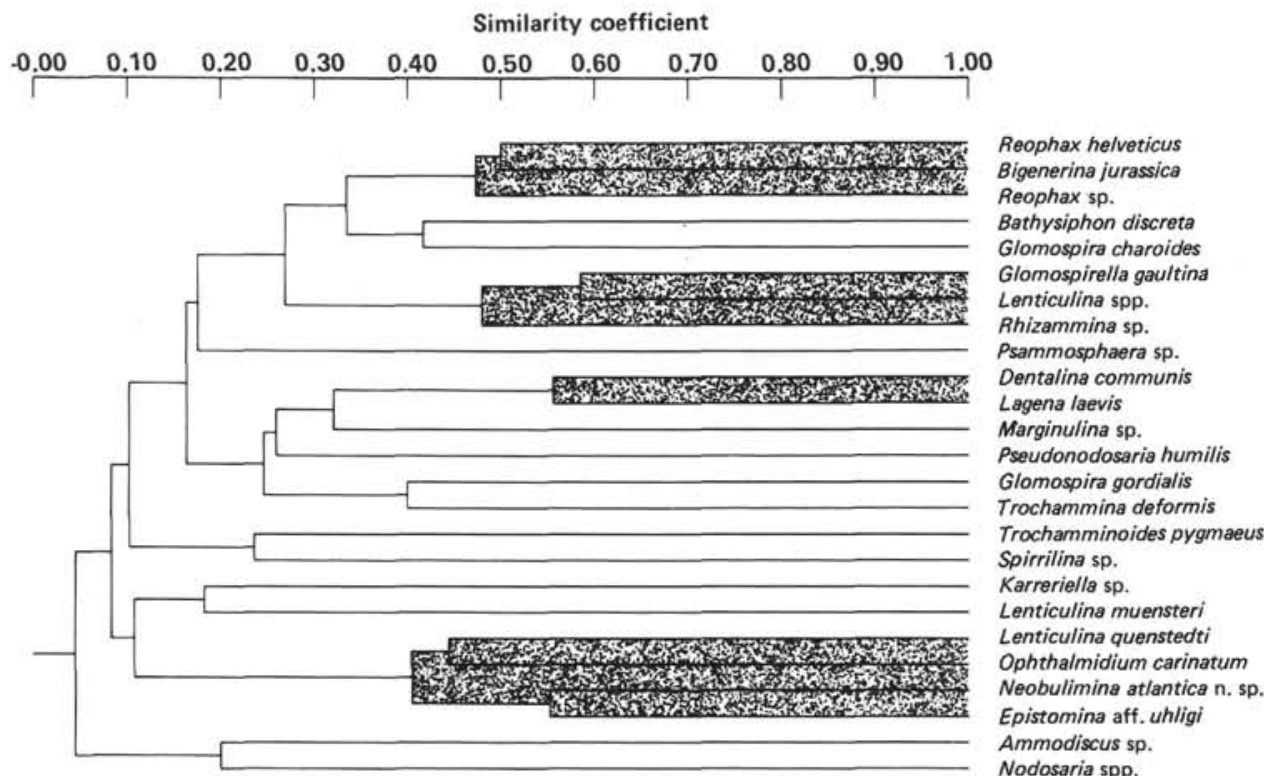

Figure 5. Dendrogram expressing the degree of association (mutual occurrences in samples) of those 25 taxa that occur in at least 5 samples. (Pattern shows "best" clusters. The method used is an R-mode clustering based on the Dice coefficient of association, with weight to the relative abundance during linkage of pairs.)

Table 2. Jurassic micropaleontological (foraminiferal) literature referred to in this study based on continental and oceanic sites, with estimates of paleo-water depth using backtracking (Sclater et al., 1977).

\begin{tabular}{|c|c|c|c|c|c|c|c|c|c|}
\hline Area & Basin & $\begin{array}{c}\text { DSDP } \\
\text { hole }\end{array}$ & Basement & $\begin{array}{c}\text { Sediment } \\
\text { on } \\
\text { basement }\end{array}$ & $\begin{array}{c}\text { Total } \\
\text { Jurassic } \\
\text { foraminiferal } \\
\text { assemblage }\end{array}$ & $\begin{array}{l}\text { Present } \\
\text { water } \\
\text { depth } \\
\text { (m) }\end{array}$ & $\begin{array}{l}\text { Sediment } \\
\text { thickness } \\
\text { (m) }\end{array}$ & $\begin{array}{l}\text { Jurassic } \\
\text { water } \\
\text { depth } \\
(\mathrm{km})\end{array}$ & Reference \\
\hline N. Atlantic & Bahama Escarpment & 99 & Not cored & Not cored & Oxf.-Kimm. & 4914 & & $<3$ & Luterbacher, 1972 \\
\hline N. Atlantic & Blake-Bahama & 100 & $M-25$ & Oxf.-Kimm. & Oxf.-Kimm.-Tith. & 5325 & & 3 & Luterbacher, 1972 \\
\hline N. Atlantic & Blake-Bahama & 105 & M-25 & Oxf.-Kimm. & Oxf.-Kimm.-Tith. & 5251 & 630 & 3 & Luterbacher, 1972 \\
\hline N. Atlantic & Blake-Bahama & $391 \mathrm{C}$ & "M-28", JQZ & Not cored & Tithonian & 4963 & 1412 & $3-3.5$ & Gradstein, 1978 \\
\hline N. Atlantic & Blake-Bahama & $534 \mathrm{~A}$ & "M-28", JQZ & m. Callovian & m. Call.-Tith. & 4974 & 1636 & $3-3.5$ & this chapter \\
\hline N. Atlantic & Moroccan Basin & 367 & JQZ edge & Oxf.-Kimm. & Oxf.-Tith.-Tith. & 4758 & & 3 & Kuznetsova and Seibold, 1978 \\
\hline N. Atlantic & Moroccan Basin & 416 & JQZ & Not cored & Tithonian & & & $3-3.5$ & Sliter, 1980 \\
\hline Indian Ocean & Argo Abyssal Plain & 216 & $M-23$ & Oxf.-Kimm. & Oxf,-Kimm.-Tith. & 5125 & 542 & 3 & Kuznetsova, 1974 Bartenstein, 1974 \\
\hline
\end{tabular}

Note: JQZ = Jurassic magnetic Quiet Zone.

assemblage (DSDP Site 261), as evidenced by 18 Oxfordian-Kimmeridgian through Berriasian-Valanginian samples from Cores 29 to 35, discussed by Kuznetsova (1974) and Bartenstein (1974). The overall similarity, as shown further on, supports the interpretation of a "comparable" abyssal environment. These authors reported 90 taxa (there are $70^{+}$in Hole 534A) in (?) 44 genera (compared to 42 in 534A), belonging in 12 families (18 in 534A).

Both the agglutinated and calcareous benthic family and generic record for the early Indian Ocean closely match those in Hole 534A. Among the calcareous taxa, the ones missing in Suite 261 are the shallow-marine contaminants (in four families) and Neobulimina n. sp., Ophthalmidium, and Globuligerina. The authors report the same high species diversity and patchy stratigraphic distribution. Relative abundance of taxa is more difficult to compare, but it appears that more common taxa in Site 261 also include Glomospirella gaultina, Glomospira charoides, G. gordialis, Dentalina communis, Spirillina, and Lenticulina. There are also common occurrenc- es of Textularia, Dorothia, Trochammina, and some different nodosariids, which is at odds with Hole 534A, but this characteristic is most likely to fluctuate from site to site, due to patchiness and sampling, and geographic and water-mass variations.

The Oxfordian-Kimmeridgian through early Neocomian assemblage studied by Luterbacher (1972) in the same general region as Site 534 also allows instructive comparison. The total number of samples more or less equals that recovered at Site 534. DSDP Site 105 has a fairly rich, quite well preserved assemblage, mainly of simple agglutinated taxa and nodosariids; a few intervals are rich in radiolarians, ostracodes, aptychi, and Saccocoma. A few samples contain almost all epistominids or are dominated by Ophthalmidium. DSDP Site 100 has a less diverse assemblage, almost all simple agglutinants and nodosariids and Spirillina.

Stratigraphically more persistent and/or locally more common taxa at Site 105 are Bathysiphon, Tolypammina, Hyperammina, Reophax, Haplophragmoides, Spirillina, Spirophthalmidium, Ophthalmidium, Epistomi- 
Table 3. Composition at the family and genus levels of Middle to Late Jurassic oceanic-abyssal and shallow-marine (?deep neritic)-epicontinental assemblages of foraminifers.

\begin{tabular}{|c|c|c|c|c|c|c|c|c|}
\hline & & \multicolumn{3}{|c|}{ Abyssal-oceanic } & \multicolumn{4}{|c|}{ Shallow marine-epicontinental } \\
\hline & & $\begin{array}{l}\text { DSDP } \\
534 \\
\text { (this } \\
\text { chapter) }\end{array}$ & $\begin{array}{c}\text { DSDP 261 } \\
\text { Kuznetsova, } 1974 \\
\text { Bartenstein, } 1974\end{array}$ & $\begin{array}{l}\text { DSDP } 100 / 105 \\
\text { Luterbacher, } 1972\end{array}$ & $\begin{array}{l}\text { Saskatchewan } \\
\text { Wall, } 1960\end{array}$ & $\begin{array}{l}\text { W. Germany } \\
\text { Lutze, } 1960\end{array}$ & $\begin{array}{l}\text { W. Germany } \\
\text { Munk, } 1980\end{array}$ & $\begin{array}{c}\text { Grand Banks } \\
\text { Gradstein, } 1977\end{array}$ \\
\hline Astrorhizidae & $\begin{array}{l}\text { Rhizammina } \\
\text { Rhabdammina } \\
\text { Bathysiphon } \\
\text { Hyperammina } \\
\text { Hippocrepina } \\
\text { Saccorhiza } \\
\text { Kalamopsis }\end{array}$ & $\begin{array}{l}x \\
x \\
x \\
x \\
x\end{array}$ & $\begin{array}{l}x \\
x \\
x \\
x\end{array}$ & $\begin{array}{l}x \\
x \\
x\end{array}$ & & & & \\
\hline Saccamminidae & $\begin{array}{l}\text { Psammosphaera } \\
\text { Pelosina } \\
\text { Sorosphaera } \\
\text { Lagenammina }\end{array}$ & $\mathrm{x}$ & $\begin{array}{l}\mathrm{X} \\
\mathrm{x}\end{array}$ & $\mathrm{x}$ & & & & \\
\hline Ammodiscidae & $\begin{array}{l}\text { Ammodiscus } \\
\text { Glomospirella } \\
\text { Glomospira } \\
\text { Lituotuba } \\
\text { Ammovertella } \\
\text { Ammolagena }\end{array}$ & $\begin{array}{l}x \\
x \\
x\end{array}$ & $\begin{array}{l}x \\
x \\
x \\
x \\
x \\
x\end{array}$ & $\begin{array}{l}\mathrm{x} \\
\mathrm{x} \\
\mathrm{x}\end{array}$ & $\begin{array}{l}\otimes \\
x\end{array}$ & & $\stackrel{\mathrm{X}}{\text { + Tolypammina }}$ & ?X \\
\hline Hormosinidae & $\begin{array}{l}\text { Hormosina } \\
\text { Reophax }\end{array}$ & $x$ & $\stackrel{x}{x}$ & $x$ & $\mathrm{x}$ & & $? \mathrm{X}$ & $\mathrm{x}$ \\
\hline Lituolidae & $\begin{array}{l}\text { Haplophragmium } \\
\text { Haplophragmoides } \\
\text { Ammobaculites } \\
\text { Placopsilina } \\
\text { Cribrostomoides }\end{array}$ & $\begin{array}{l}x \\
x\end{array}$ & $\begin{array}{l}x \\
x \\
x \\
x\end{array}$ & $\begin{array}{l}\mathrm{X} \\
\mathrm{X} \\
\mathrm{X} \\
? \mathrm{X}\end{array}$ & $\bigotimes_{+ \text {Ammomarginulina }}^{\mathrm{X}}$ & $\begin{array}{l}\mathrm{x} \\
\mathrm{x}\end{array}$ & $\mathrm{x}$ & $\begin{array}{l}\mathrm{x} \\
\mathrm{x}\end{array}$ \\
\hline Trochamminidae & $\begin{array}{l}\text { Trochammina } \\
\text { Trochamminoides }\end{array}$ & $\begin{array}{l}x \\
x\end{array}$ & $\otimes$ & $\mathrm{x}$ & $\mathrm{x}$ & $\mathrm{x}$ & & $\mathrm{x}$ \\
\hline Ataxophragmiidae & $\begin{array}{l}\text { Dorothia } \\
\text { Gaudryina } \\
\text { Karreriella } \\
\text { Verneuillina }\end{array}$ & $\begin{array}{l}x \\
x \\
x \\
x\end{array}$ & $\begin{array}{l}x \\
x\end{array}$ & 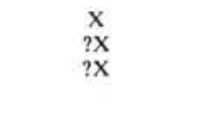 & $\mathrm{x}$ & $\mathrm{x}$ & & $\begin{array}{l}x \\
x\end{array}$ \\
\hline Textulariidae & $\begin{array}{l}\text { Spiroplectammina } \\
\text { Textularia } \\
\text { Bigenerina }\end{array}$ & $\begin{array}{l}\mathrm{x} \\
\mathrm{x} \\
\mathrm{x}\end{array}$ & $\begin{array}{l}\mathrm{x} \\
\mathrm{x}\end{array}$ & $\begin{array}{l}\mathrm{x} \\
\mathrm{X} \\
\mathrm{x}\end{array}$ & $\begin{array}{c}+ \text { Triplasia } \\
\text { Ammobaculoides }\end{array}$ & $+\underset{\mathrm{X}}{+ \text { Triplasia }}$ & $\mathrm{x}$ & \\
\hline Nodosariidae & $\begin{array}{l}\text { Lenticulina } \text { (incl. Darbyella) } \\
\text { Dentalina } \\
\text { Pseudonodosaria } \\
\text { Nodosaria } \\
\text { Frondicularia } \\
\text { Palmula } \\
\text { Lingulina } \\
\text { Marginulina } \\
\text { Ramulina } \\
\text { Saracenaria } \\
\text { Lagena } \\
\text { Vaginulina } \\
\text { Planularia } \\
\text { Bojarkaella } \\
\text { Astacolus } \\
\text { Oolina }\end{array}$ & $\begin{array}{l}\otimes \\
\otimes \\
X \\
\otimes \\
X \\
x \\
x \\
x \\
x \\
x \\
x \\
x\end{array}$ & $\begin{array}{l}\otimes \\
\otimes \\
X \\
\otimes \\
X \\
x \\
x \\
x \\
x \\
x \\
x \\
x \\
x \\
x \\
x\end{array}$ & $\begin{array}{l}\otimes \\
\otimes \\
\otimes \\
\otimes \\
\otimes \\
X \\
x \\
x \\
x \\
x \\
x \\
\otimes \\
x \\
\otimes \\
\otimes\end{array}$ & 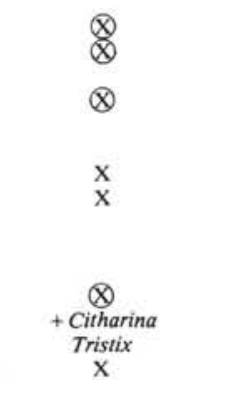 & $\begin{array}{l}\underset{\mathrm{X}}{\otimes} \\
\mathrm{x} \\
\underset{\mathrm{X}}{\mathrm{X}} \\
\mathrm{x}\end{array}$ & $\begin{array}{l}\otimes \\
\otimes \\
X \\
X \\
X \\
X \\
X \\
X \\
X \\
X \\
X \\
X \\
+ \text { Citharina }\end{array}$ & $\begin{array}{l}\underset{\mathrm{X}}{\otimes} \\
\mathrm{x} \\
\mathrm{x}\end{array}$ \\
\hline Polymorphinidae & $\begin{array}{l}\text { Guttulina } \\
\text { Eoguttulina } \\
\text { Globulina } \\
\text { Rectoglandulina }\end{array}$ & $\mathrm{x}$ & & $\begin{array}{l}x \\
x\end{array}$ & $\begin{array}{l}x \\
x \\
x\end{array}$ & $\begin{array}{l}x \\
x\end{array}$ & $\mathrm{x}$ & $\mathrm{x}$ \\
\hline Turrilinidae & Neobulimina & $\mathrm{x}$ & ?X & & & & & \\
\hline Ceratobuliminidae & Epistomina & $\mathrm{x}$ & & $\mathrm{x}$ & Conorboides & $\underset{\text { Conorboides }}{\mathrm{X}}$ & $x$ & Reinholdella \\
\hline Nubeculariidae & $\begin{array}{l}\text { Ophthalmidium } \\
\text { Nubeculinella }\end{array}$ & $\mathrm{x}$ & $\mathrm{x}$ & $\begin{array}{l}\mathrm{X} \\
\mathrm{x}\end{array}$ & $\begin{array}{l}x \\
x\end{array}$ & $\begin{array}{l}\mathrm{X} \\
\mathrm{x}\end{array}$ & $\begin{array}{l}x \\
x\end{array}$ & $\mathrm{x}$ \\
\hline Spirrilinidae & Spirrilina & $\mathrm{x}$ & $\mathrm{x}$ & $\mathrm{x}$ & $\mathrm{x}$ & $\mathrm{x}$ & $\otimes$ & $\mathrm{x}$ \\
\hline Globigerinidae & Globuligerina & $\mathrm{x}$ & & $\mathrm{x}$ & & & & $\mathrm{x}$ \\
\hline Note: Genera with & A more species a & & & & $\begin{array}{l}\text { +Quinquelocu } \\
\text { Massilina } \\
\text { Miliammina }\end{array}$ & $\begin{array}{r}\text { na }+ \text { Paalzow } \\
\text { Trocholi } \\
\text { Bullopor }\end{array}$ & $\begin{array}{l}\text { ella } \\
\text { ina } \\
-a\end{array}$ & $\begin{array}{l}+ \text { Paalzowella } \\
\text { Patellina }\end{array}$ \\
\hline
\end{tabular}

na, Dentalina, Lenticulina, Astacolus, Pseudonodosaria, and Marsonella. At Site 100 this list is shorter. The listing includes many of the persistent Site 534 genera. The overall micropaleontological characterization of Sites 105 and 100 , taxonomic affinity at the genus level of $70 \%$, and family representation well compare to Site
534. The sporadic occurrence of glomospirid-type forms and the absence of Neobulimina are notable differences.

In summary, the Atlantic and Indian oceans abyssal Middle-Late Jurassic foraminiferal "fauna" has a high species (100) and high generic (50) diversity, patchy specimen representation, and low communality at the 
species level. The assemblage consists principally of small-sized agglutinated taxa in eight or so families, small-sized nodosariids in a dozen or so genera, and variable additions of epistominids, ophthalmidids, spirillinids, and turrilinids. The assemblage is accompanied by radiolarians, calcispherulids, aptychi, and Saccoco$m a$, and, except for calcispherulids, Saccocoma, and a few index foraminifers, continues into the Early Cretaceous.

The question should be asked how different the (deep) neritic Late Jurassic fauna was from the deep sea ones, particularly because niches probably were broader than today. The Late Cretaceous through Recent record is of much higher diversity in families, genera, and species in a physically more differentiated marine environment. Although the following taxonomic-paleoecologic comparison far from answers that question, it provides some insight into Jurassic paleoecological relationships, as a practical aid to further interpretation.

Table 3 lists the genera found in shallow-marine-epicontinental deposits of Saskatchewan (Wall, 1960), West Germany (Lutze, 1960; Munk, 1980-Feuerstein Bank only) and the Grand Banks (Gradstein, 1977, and unpublished data). This record was limited to a deep neritic environment, using mainly broad geological criteria and biofacies trends. I exclude the shallow-marine, photic zone record, which in lower latitudes includes larger foraminifers. As is the case with the comparative record for the oceanic sites, there is some taxonomic bias, but it is minor in view of the extent of the record.

Major differences in the neritic record (Table 3) are the lack of many simple agglutinated genera, a much less complete representation of agglutinated families, the presence of large Ammobaculites and Ammomarginulina, and the presence among the calcareous forms of Miliammina, Trocholina, Patellina and Paalzowella, and
Citharina and Tristix. Specimens are on average larger than in the oceanic realm, and many more sculptured taxa occur. There seems to be no striking difference in comparing the score of genera with the highest species diversity (5); but the diversity in the shallow-marine, neritic record of epistominids, Ammobaculites, and spirillinids (which, according to Munk's [1980] detailed and quantitative study, flourish in reefal environment) is not found in the oceanic sites.

The extensive, although relatively specimen-poor, agglutinated record in the Jurassic abyssal sites provides a link to more modern deep-marine assemblages ("fauna"). Many of the more simple agglutinated genera probably evolved little or not at all through time and may be of Paleozoic origin. In contrast, the Jurassic calcareous record, which goes back into the Triassic, is preactualistic. Nodosariid- or, for example, epistominiddominated assemblages disappeared after the Early Cretaceous.

Figures 6 and 7 provide some insight into the composition of deep-water agglutinated assemblages through time. Compositional data are based on my comparative research using actual collection of Brady's (1884) Recent ocean benthos fauna, the Recent Newfoundland slope fauna (Schafer and Carter, 1981), the Maestrichtian through Paleogene of the Labrador and Newfoundland shelves, and the Paleogene of the Central North Sea (Gradstein and Berggren, 1981), the Maestrichtian and Paleocene Guayaguare and Lizard Spring Formations of Trinidad, and the early Eocene Discovery and Scoresby dredges on Burdwood Bank, southwestern Atlantic Ocean (Gradstein, unpublished data). In some of the listed geological sites, agglutinated taxa predominated among the foraminifers but such is not necessarily the case in the Recent. There is a strong resemblance in overall composition of the Maestrichtian through $\mathrm{Pa}$ -
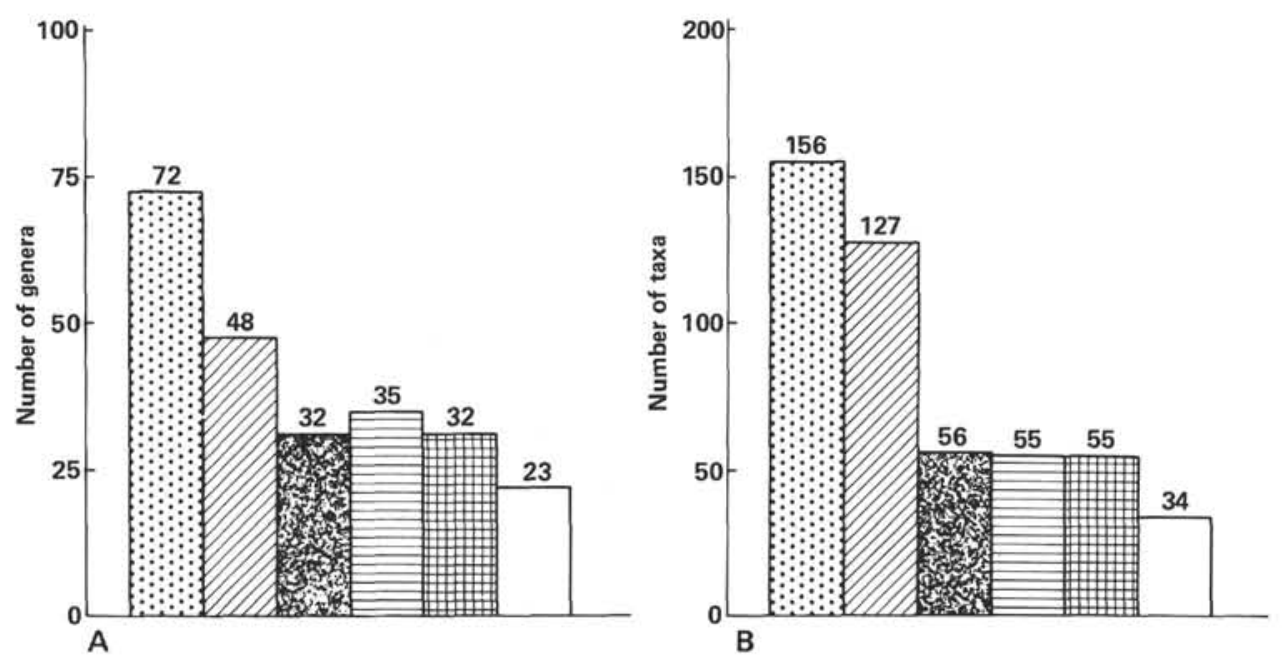

Figure 6. A. Number of genera of agglutinated foraminifers recognized in Cores 534A-70 to 127, Callovian-Neocomian, western North Atlantic Ocean. (For legend see Fig. 7.) (Communality of the Hole $534 \mathrm{~A}$ assemblage with the other deep-water [bathyal-abyssal] assemblages is over $95 \%$ [at the genus level]. This figure varies little from older site to younger site through time, although the number of genera evolved, preserved, and/or recovered increased through time.) B. Number of taxa of agglutinated foraminifers recognized at the sites of Figure 6A. (Communality of the Site 534 assemblage with the other [younger] assemblages at the species level is less than $15 \%$ [see text].) 

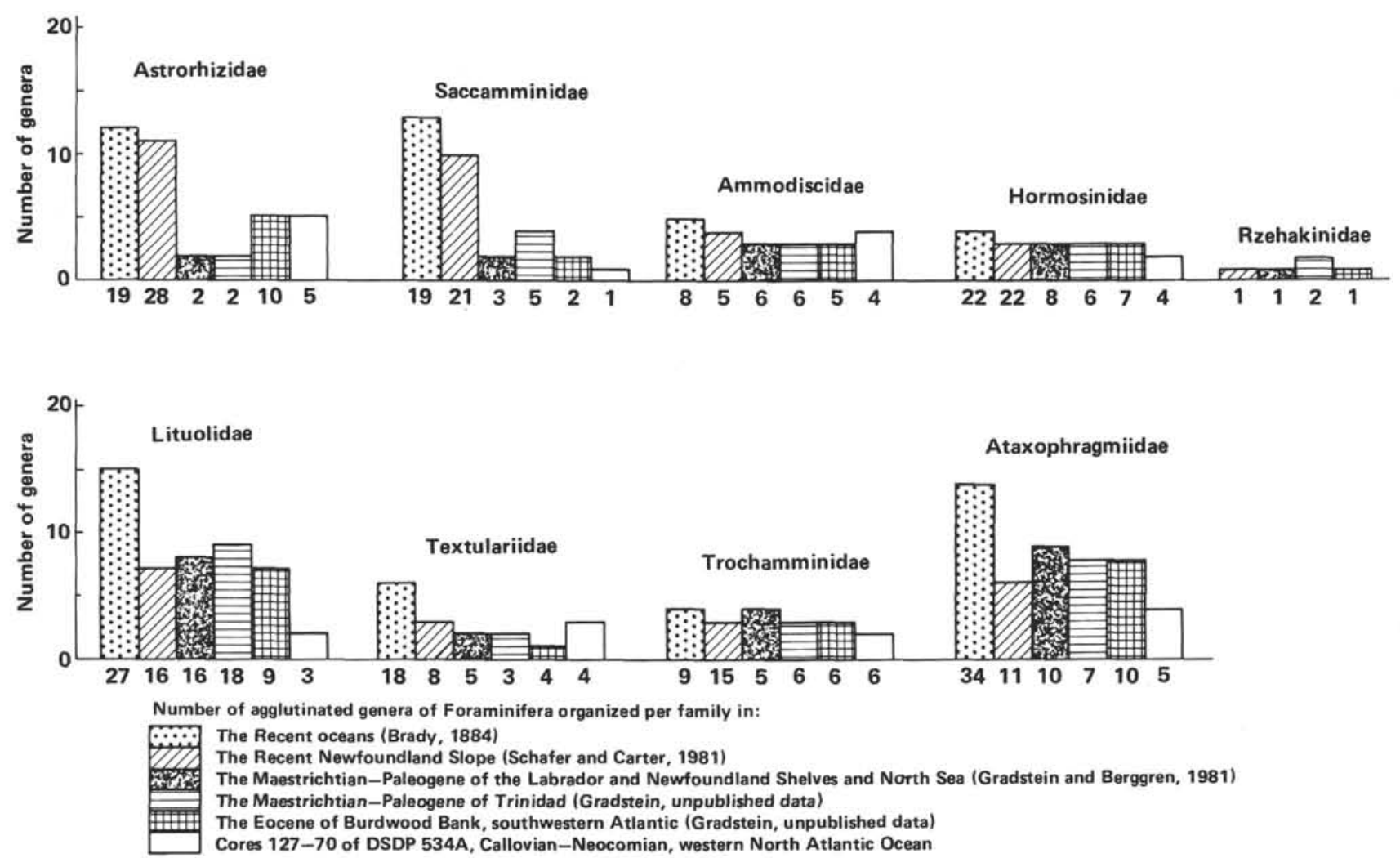

Figure 7. Number of genera of agglutinated foraminifers organized per family in Cores 534A-70 to 127, Callovian-Neocomian, western North Atlantic Ocean. (At the bottom of each bar is the number of taxa recognized. Family representation is essentially equal through time for all of these deep-marine assemblages, but the relative proportion of genera varies. In general the Recent bathyal-abyssal fauna has the highest number of genera evolved and recovered. Note the low number of Lituolidae and Ataxophragmiidae in the Jurassic assemblage of Hole 534A. Among the Astrorhizidae and Saccamminidae there are many delicate tests that do not preserve in the fossil record.)

leogene assemblages and the Recent slope or ocean faunas, both at the genus and family levels. Also, the same genera, for example, dominate the Newfoundland $\mathrm{Pa}$ leogene and Recent slope, but communality at the species level is only 12 to $15 \%$, the result of evolutionary turnover. A more detailed discussion is presented by Scott et al. (in press).

Similarity of the Hole 534A Jurassic agglutinated assemblage with geologically younger ones is over $95 \%$ at the genus level. Virtually all of the 23 Jurassic genera also form part of the geologically younger assemblages, but specimens are relatively small and not particularly coarse grained. In the Cretaceous and Tertiary new genera appear like Uvigerinammina, Rzehakina, Cystammina, Recurvoides(?), Plectina, Cyclammina. And the Recent record has many delicate forms that do not fossilize; it also has been much more split.

The number of agglutinated taxa recognized in Hole $534 \mathrm{~A}$ is also lower by a factor of 1.5 to 4 , and species similarity with younger sites is only about $15 \%$ or less, with Bathysiphon discreta, Glomospira charoides, G. gordialis, G. irregularis, Reophax aff. horridus, Trochammina globigeriniformis, and $T$. aff. deformis. The majority of species in Hole 534A probably disappeared in the Early Cretaceous.

At the family level the assemblages from the stratigraphically different sites are essentially equal, but the relative proportion of genera per family varies. Again, the Recent bathyal-abyssal fauna has the highest number of genera recovered and recorded (Scott et al., in press), and the Jurassic assemblage in Hole 534A has a relatively low number of Lituolidae and Ataxophragmiidae.

The comparative taxonomic study of the agglutinated component of the Jurassic oceanic assemblage indicates relative taxonomic stability above the species level in time. This conclusion can be used to delineate fossil assemblages in the major oceanic or clastic wedge-slope environments. Comparison suffers in the sense that the proportion of each taxonomic unit may vary from geologic site to site and in each site from sample to sample. As far as Hole 534A is concerned, specimens are smaller and much less numerous than in the other geological sites, which may reflect abyssal-plain versus clastic-wedge slope conditions. The fact remains that diversity is high, as opposed to more monotypic, shallow-marine, neritic faunas. The Jurassic agglutinated assemblage in Hole $534 \mathrm{~A}$ has a remarkable communality above the species level to geologically younger deep-marine assemblages.

\section{BIOSTRATIGRAPHY}

An evaluation of the distribution in time of the Jurassic foraminifers in Hole 534A follows three avenues. First, there is a distribution chart of selected taxa with distinct stratigraphic range (Fig. 8); secondly, the local relative ranges are compared to the literature; thirdly, 


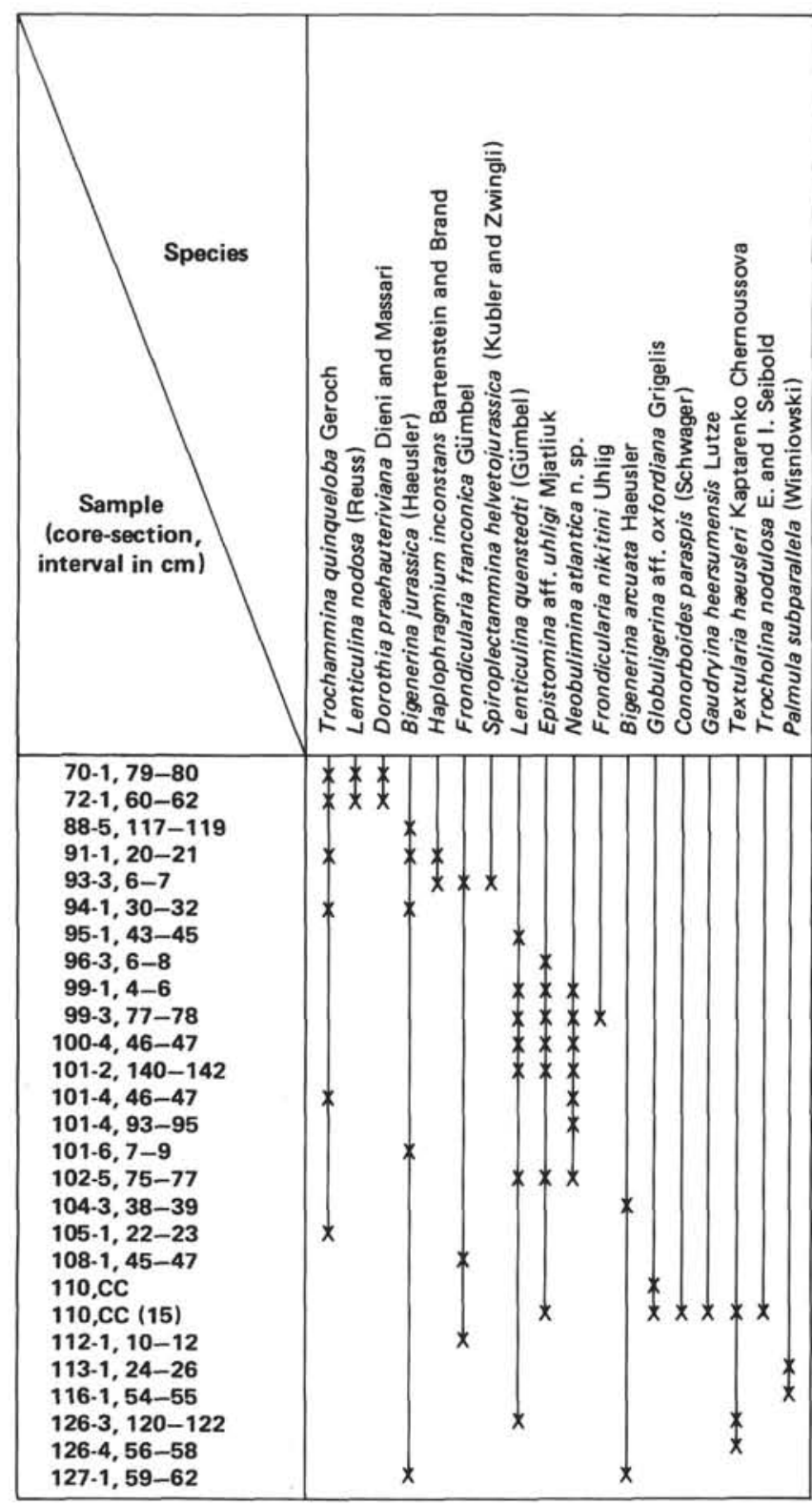

Figure 8. Distribution of stratigraphically useful (or potentially so) foraminiferal species in Cores 534A-70 to -127 .

the chronostratigraphic interpretation is compared to the multiple chronostratigraphy in Hole 534A (Fig. 9), on the basis of reports on nannofossils (Roth, Medd, and Watkins), dinoflagellates (D. Habib and W. Drugg), radiolarians (P. Baumgartner), calpionellids (J. Remane), ammonites and aptychi (O. Renz), and ostracodes $(\mathrm{H}$. Oertli) (this volume).

A range chart (Fig. 8) of 18 taxa that have a distinct relative stratigraphic distribution or are reportedly of "zonal" use shows at least three shoulders. There is a basal assemblage, concentrated in Core 110 with Palmula subparallela, Trocholina nodulosa, Textularia haeusleri, Gaudryina heersumensis, Conorboides paraspis, and Globuligerina aff. oxfordiana. The next assemblage, which appears and disappears in Cores 102 to 95 , includes Neobulimina atlantica n. sp., Epistomina aff. uhligi,
Lenticulina quenstedti, and an occurrence of Frondicularia nikitini. At the top of the section studied there are Lenticulina nodosa and Dorothia praehauteriviana in Cores 72 to 70 , together with Trochammina quinquelo$b a$. The latter first appears in Core 105 .

A chronostratigraphic evaluation of the "shoulders" suggests the Oxfordian for the basal one in Core 110, the Kimmeridgian-Tithonian for Cores 102 through 95, and the late Valanginian for Core 72 and up. The biostratigraphic correlation potential of the assemblages in the Atlantic realm (Luterbacher, 1972; Kuznetsova, 1974; Gradstein, 1977, 1978; Jansa et al. 1979, 1980; Sliter, 1980) is as follows.

There is a first-order correlation of the co-occurrence of Dorothia praehauteriviana and Lenticulina nodosa, which correlates Cores 72 and up in Hole 534A to Hole $391 \mathrm{C}$, Cores 24 to 26 , to Hole 101A, Core 10 , and to Hole 105, Cores 19 to 21, all in the northwestern Atlantic abyssal plain. The most likely age is late Valanginian. The same co-occurrence is reported in the eastern North Atlantic in Holes 370, Cores 38 to 46, and 416, Cores 10 to 22, also dated late Valanginian.

The co-occurrence of Lenticulina quenstedti and Epistomina aff. uhligi in Cores 102 to 96 in Hole 534A correlates directly to Cores 50 to 52 in Hole $391 \mathrm{C}$, to Cores 36 to 37 in Hole 105, and to Cores 35 to 37 in Hole 367 . The most likely age for this event is Kimmeridgian, although both taxa on the Grand Banks are known to occur together in strata as old as the Garantella Zone, Bajocian-Bathonian, extending upward to the level of Alveosepta jaccardi, late Oxfordian-Kimmeridgian. Only the uppermost co-occurrence may be as young as the Kimmeridgian.

The co-occurrence in Core 110 of Conorboides paraspis, Gaudryina heersumensis, Textularia haeusleri, Trocholina nodulosa, and Globuligerina aff. oxfordiana has no correlative equivalent to any other DSDP sites; this lack of correlation agrees with the fact that at none of the other sites were strata underlying the Cat Gap Formation penetrated and recovered. The age of the assemblage is likely Oxfordian (see Oesterle, 1968; Lutze, 1960), which agrees with the lack of a record of Jurassic planktonic foraminifers in circum-Atlantic basins above the Oxfordian. This Late Jurassic planktonic record is based on rich occurrences in the Hauffianum Zone in Portugal (Gradstein, unpublished data; Plate 2, Figs. $18,19)$, the Mariae Zone in France (Bignot and Guyader, 1966), the Transversarium Zone off Morocco (Renz et al., 1975), and the lower Epistomina mosquensis Zone on the Grand Banks (Gradstein, 1977). The fact that taxa in Core 110 probably were introduced from a shallower environment might lead to too old an age estimate for the actual sediments of Core 110, but microfossil transportation may well have happened during the stratigraphic life span of the taxa. There certainly is no stratigraphic discrepancy in the foraminiferal record of the cores.

It may be feasible to make miscellaneous correlations between Atlantic Site 534 and Site 261 in the Indian Ocean (Kuznetsova, 1974) using Trochammina quinqueloba (Oxfordian-Kimmeridgian into Valanginian) and 


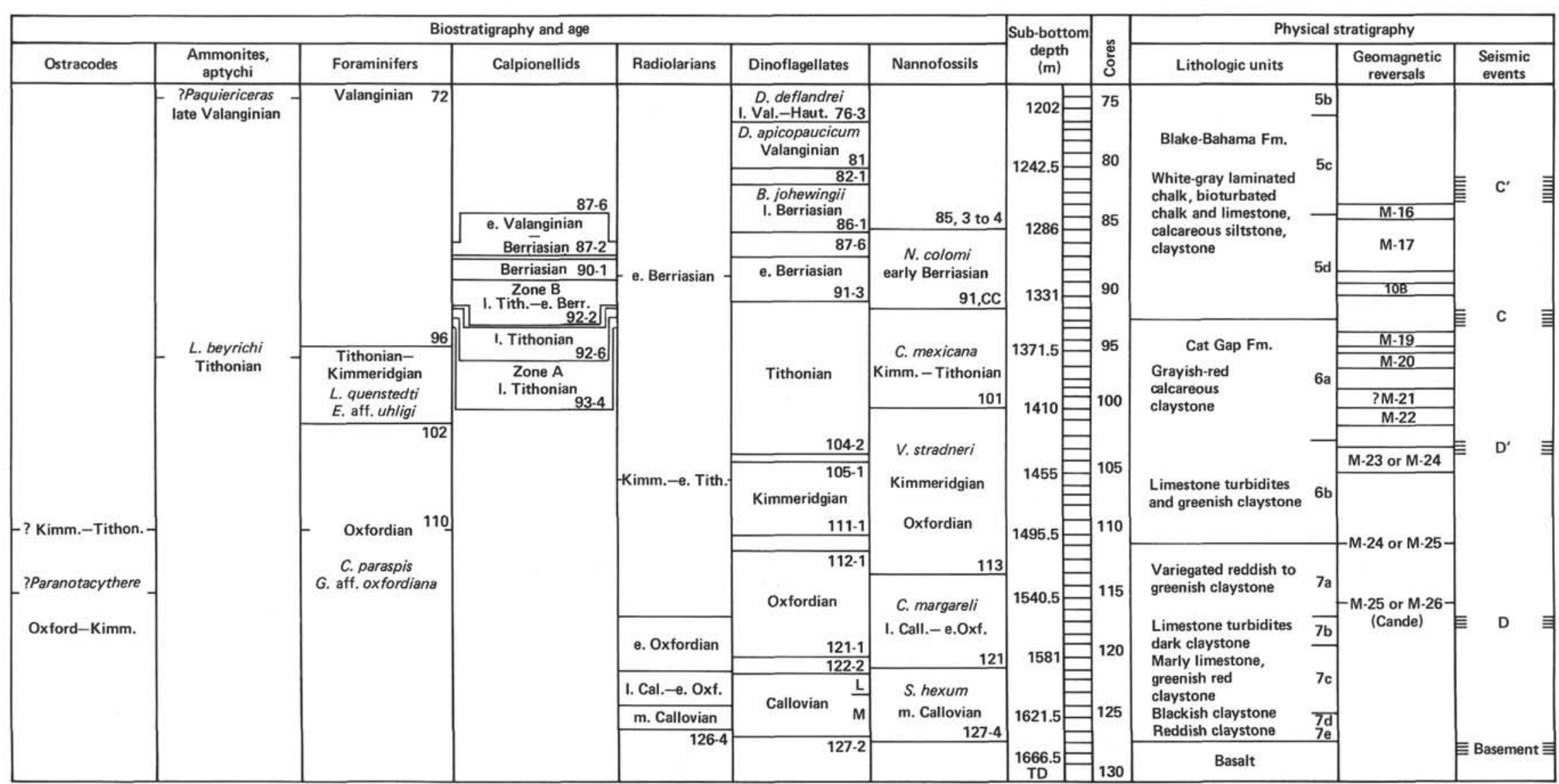

Figure 9. Biostratigraphy, age assignments, lithological units, geomagnetic reversals, and seismostratigraphic events in the Jurassic to Earliest Cretaceous deposits of Hole 534A, BlakeBahama Basin. (Data follow H. Oertli-ostracodes, ammonites-O. Renz; foraminifers-this chapter; calpionellids-J. Remane; radiolarians-P. Baumgartner; dinoflagellates-D. Habib and W. Drugg; nannofossils-P. Roth, A. Medd, D. Watkins; geomagnetic reversals - J. Ogg; seismostratigraphic events-R. Sheridan, T. Shipley, et al. [all references to this volume].) 
Haplophragmoides inconstans (Tithonian-Berriasian into Valanginian). Future studies will verify and extend more detailed correlations using some of the taxa listed in Figure 8.

The chronostratigraphic interpretations using different microfossil disciplines are summarized in Figure 9. The figure clearly shows the agreement using radiolarians (Unitary Associations 0 and 1 of Baumgartner, this volume), nannofossils (Stephanolithion hexum assemblage), and middle Callovian dinoflagellates of the basal claystone beds of lithologic Subunits $7 \mathrm{~d}$ and e. These beds lack a diagnostic foraminiferal assemblage, as, for example, occurs on the Grand Banks, with Reinholdella crebra Pazdro var. and Epistomina regularis Terquem (Gradstein, 1977).

There is also good agreement on the upper limit of the Cat Gap Formation (Core 92), the top of the Tithonian nannofossil Conusphaera mexicana Zone, the top of the palynological Tithonian, and the position of calpionellid Zone B, which straddles the Jurassic/Cretaceous boundary in Cores 91 to 90 . There is no useful record based on abyssal foraminifers at this boundary.

The foraminiferal assemblage with Conorboides paraspis in Core 110, dated Oxfordian, could be considered to be slightly reworked using the Oxfordian/Kimmeridgian boundary based on dinoflagellates in Cores 112 to 111 , but one core difference is limited inaccuracy, given the meager record. The nannofossil assemblage of $\mathrm{Va}$ galapilla stradneri at these depths is listed as Oxfordian-Kimmeridgian. Geomagnetically, the Conorboides assemblage correlates to M-24 or M-25 (J. Ogg, this volume), which is supposed to be the signature of basement in DSDP Site 105. The basal sediment in Site 105 hence could be geologically slightly younger and of lithologic Subunit $6 \mathrm{~b}$ character, which it is. This reasoning agrees with the absence of the Conorboides assemblage in Site 105 .

The assemblage with Lenticulina quenstedti in Cores 102 through 95, dated Kimmeridgian, may well extend into Tithonian beds if we consider the local floral stratigraphies, although such would be unique to the deep sea. The upper assemblage in Cores 72 to 70 with Dorothia praehauteriviana of the late Valanginian connotation correlates well with chronostratigraphic assignments, using the late Valanginian Paquiericeras ammonite in Core 75 (O. Renz, this volume) and the lower part of the Druggidium deflandrei dinoflagellate zone from Core 76 and up (D. Habib, this volume).

\section{TAXONOMIC NOTES}

Neobulimina atlantica n. sp.

(Plate 3, Figs. 1-12)

Diagnosis. A neobuliminid with a short, flaring test, almost as wide as high; the triserial stage is confined to the apex and is poorly visible; the biserial stage can be slightly twisted and is broadly elliptical in cross section.

Description. Early stage triserial, almost hidden in the initial, apical portion of the test. The biserial stage makes up $95 \%$ of the total test and consists of 2,3, or 4 pairs of chambers, which rapidly increase in size such that the test width approaches or equals the length; chambers inflated, sutures slightly incised; test cross section elliptical with broadly rounded ends; wall calcareous (tested with $10 \% \mathrm{HCl}$ ), distinctly perforate, and with a slightly pitted (punctate) appearance; apertur- al face depressed with a large, loop-shaped aperture visible in the last chamber. The smallest specimen found measured $60 \mu \mathrm{m}$ (width) by 75 $\mu \mathrm{m}$ (length), and the largest one $225 \mu \mathrm{m}$ (width) by $250 \mu \mathrm{m}$ (length).

The Catalogue of Foraminifera (Ellis, Messina, et al., 1940-1982) lists 12 species of Neobulimina in the Upper Jurassic $(1 \times)$, Cretaceous $(6 \times)$, and Tertiary $(5 x)$ strata. All of the known taxa are much longer, with a more slender build and a more exposed and pronounced triserial stage than the specimens of Hole 534A. For example, in $N$. varsoviensis Bielecka and Pozaryski from the Upper Jurassic of Central Poland, the triserial stage takes 20 to $50 \%$ of the test and the biserial stage has up to nine pairs of chambers. In the new taxon $N$. atlantica, the triserial part is generally $5 \%$ or less of the test length and the biserial part has less than half of the biserial chambers of $N$. varsoviensis.

Specimens and photographs of $N$. atlantica were studied by S. Geroch (Krakow), I. Premoli Silva (Milano), M. Moullade (Nice), W. V. Sliter (Washington), P. Ascoli (Dartmouth, N.S.), and H. P. Luterbacher (Tübingen). None of these colleagues is aware of a comparable record of $N$. atlantica $\mathrm{n} . \mathrm{sp}$. in the existing literature.

Type locality and type material. The assemblage of $N$. atlantica $\mathrm{n}$. sp. consists of a hundred or more specimens in Cores 99 through 102 of DSDP Hole 534A, northwestern Atlantic Ocean. The cored interval is in the Cat Gap Formation of the Late Jurassic. Lenticulina quenstedti (Gumbel) and Epistomina aff. uhligi Mjatliuk occur in the same cored interval, which also contains some specimens of Trochammina quinqueloba Mjatliuk and Frondicularia nikitini Uhlig. Nannofossils (Roth et al., this volume) indicate the presence of the Vagalapilla stradneri and Conusphaera mexicana Zones (Kimmeridgian-Tithonian), whereas D. Habib and W. Drugg (this volume) suggest the Tithonian using dinoflagellates. Foraminifers rather suggest the Kimmeridgian-Tithonian, because $L$. quenstedti appears to have only been recorded so far from pre-Tithonian strata. The holotype (Plate 3, Figs. 1, 2) and paratypes (Plate 3, Figs. 3-12) have been deposited with the Deep Sea Drilling Collection of the Smithsonian Institute, Washington, D.C., U.S.A.

\section{Epistomina aff. uhligi Mjatliuk}

(Plate 4, Figs. 1-5)

Specimens vary in degree of convexity of the spiral and umbilical sides, in degree of thickening of the sutures (limbate to smooth), and in the degree of development of the umbo. Both spiroconvex, planoconvex, and biconvex types occur.

Specimens in Cores 534A-110 to 96 belong to the Late Jurassic branch of smooth epistominids, for which Epistomina uhligi Mjatliuk is the usual name. DSDP Hole 534A specimens show a larger variation in the thickness of spiral suture (which varies from thin to much pronounced and limbate) than do those described by Ohm (1967).

Some of the DSDP Hole 534A specimens of $E$. aff. uhligi compare to Brotzenia sp. ex. gr. B. parastelligera (Hofker), as recognized by Luterbacher (1972) at DSDP Site 105.

The abyssal western North Atlantic Late Jurassic deposits show none of the abundance in small, reticulate epistominids, as seen in North American Atlantic margin deposits of a shallow neritic facies.

\section{ACKNOWLEDGMENTS}

I gratefully acknowledge the advice and technical support of I. Premoli Silva, D. Habib, M. Moullade, H. Oertli, H. P. Luterbacher, C. Schafer, G. Bonham-Carter, L. Johnston, Carol Mitchell, F. Thomas, and G. Cook.

\section{REFERENCES}

Barker, R. W., 1960. Taxonomic notes on the species figured by H. B. Brady in his Report on the Foraminifera dredge by HMS Challenger during the years 1873-1876. Soc. Econ. Paleontol. Mineral., Spec. Publ., 9:1-238.

Barnard, T., and Shipp, D. J., 1981. Kimmeridgian Foraminifera from the Boulonnais. Rev. Micropaleontol., 24(1):3-26.

Bartenstein, H., 1974. Upper Jurassic-Lower Cretaceous primitive arenaceous Foraminifera from DSDP Sites 259 and 261, eastern Indian Ocean. In Veevers, J. J., Heirtzler, J. R., et al., Init. Repts. $D S D P, 27$ : Washington (U.S. Govt. Printing Office), 683-695.

Bartenstein, H., and Brand, E., 1951. Micropalaontologische Untersuchungen zur Stratigraphie des nordwestdeutschen Valendis. Anh. Senckenb. Naturforsch. Ges., 485:1-336. 
Benson, W. E., Sheridan, R. E., et al., 1978. Init. Repts. DSDP, 44: Washington U.S. Govt. Printing Office).

Bielecka, W., and Geroch, S., 1977. Quelque foraminifères du Jurassique superieur des Carpathes externes polonaises. Actes VI Coll. Africain, Tunis, 1974. Mines et Geol. Tunis, 28:185-199.

Bignot, G., and Guyader, J., 1966. Decouverte de Foraminiferes planctoniques dans l'Oxfordien du Havre (Seine) Maritime. Rev. Micropaleontol., 2(9):104-110.

Bonham-Carter, G., 1967. Fortran IV program for Q-mode cluster analysis of non-quantitative data using IBM 7090/7094 computers. Univ. Kans. Computer Contr., 17:1-13.

Brady, H. B., 1884. The voyage of H.M.S. Challenger. Zoology (IX), $1,2: 1-814$.

Bryan, G. M., Markl, R. G., and Sheridan, R. E., 1980. IPOD Site surveys in the Blake-Bahama Basin. Mar. Geol., 35:43-63.

Cheetham, A. H., and Hazel, J. E., 1969. Binary (presence-absence) similarity coefficients. J. Paleontol., 43(5):1130-1136.

Cole, F. E., 1981. Taxonomic notes on bathyal zone foraminiferal species off northeast Newfoundland. Bedford Inst. Oceanogr. Rep. Ser. BIO 81-7.

Ellis, B. T., Messina, A. R., et al., 1940-1982. Catalogue of Foraminifera: New York (Spec. Publ. Am. Mus. Nat. Hist.).

Farinacci, A., 1965. I Foraminiferi di un livello marnoso nei calcari diasprigni del Malm (Monti Martani, Umbria). Geol. Rom., 4: 229-258.

Gradstein, F. M., 1977. Biostratigraphy and biogeography of Jurassic Grand Banks Foraminifera. Ist Int. Symp. Benthonic Foraminifera (B); Mar. Sedimentol. Spec. Publ., 1:557-583.

1978. Biostratigraphy of Lower Cretaceous Blake Nose and Blake-Bahama Basin Foraminifers, DSDP Leg 44, western North Atlantic Ocean. In Benson, W. E., Sheridan, R. E., et al., Init. Repts. DSDP, 44: Washington (U.S. Govt. Printing Office), 663-701.

Gradstein, F. M., and Berggren, W. A., 1981. Flysch-type agglutinated Foraminifera and the Maestrichtian to Paleogene history of the Labrador and North Seas. Mar. Micropaleontol., 6(1981): 211-268.

Hollister, C. D., Ewing, J. I., et al., 1972. Init. Repts. DSDP, 11: Washington (U.S. Govt. Printing Office).

Jansa, L. F., Enos, P., Tuckolke, B. F., Gradstein, F. M., and Sheridan, R. E., 1979. Mesozoic-Cenozoic sedimentary formations of the North American Basin, western North Atlantic. Am. Geophys. Union, Maurice Ewing Series, 3:1-57.

Jansa, L. F., Remane, J., and Ascoli, P., 1980. Calpionellid and foraminiferal-ostracod biostratigraphy at the Jurassic-Cretaceous boundary, offshore eastern Canada. Riv. Ital. Paleontol., 86(1): $67-126$.

Kuznetsova, K. I., 1974. Distribution of benthonic Foraminifera in Upper Jurassic and Lower Cretaceous deposits at Site 261, DSDP Leg 27, in the eastern Indian Ocean. In Veevers, J. J., Heirtzler, J. R., et al., Init. Repts. DSDP, 27: Washington (U.S. Govt. Printing Office), 673-682.

Kuznetsova, K. I., and Seibold, I., 1978. Foraminifers from the Upper Jurassic and Lower Cretaceous of the eastern Atlantic (DSDP
Leg 41, Sites 367 and 370). In Lancelot, Y., and Seibold, E., et al., Init. Repts. DSDP, 41: Washington (U.S. Govt. Printing Office), 515-537.

Lancelot, Y., Seibold, E., et al., 1978. Init. Repts. DSDP, 41: Washington (U.S. Govt. Printing Office).

Lancelot, Y., Winterer, E. L., et al., 1980. Init. Repts. DSDP, 50: Washington (U.S. Govt. Printing Office)

Larson, R. L., Schlanger, S. O., et al., 1981. Init. Repts. DSDP, 61: Washington (U.S. Govt. Printing Office).

Luterbacher, H., 1972. Foraminifera from the Lower Cretaceous and Upper Jurassic of the Northwestern Atlantic Ocean. In Hollister, C. D., Ewing, J. I., et al., Init. Repts. DSDP, 11: Washington (U.S. Govt. Printing Office), 561-591.

Lutze, G. H., 1960. Zur Stratigraphie und Palaontologie des Callovien und Oxfordien in Nordwest-Deutschland. Geol. Jahrb., 77: 391-532.

Munk, C., 1980. Foraminiferen aus dem unteren Kimmeridge (Platynota-Schichten) der Nordlichen und Mittleren Frankenalb-Faunenbestand und Palökologie. Facies, 2:149-218.

Oesterle, H., 1968. Foraminiferen der Typlokalitat der BirmenstorferSchichten, unterer Malm. Eclogae Geol. Helv, 61(2):695-792.

Ohm, U., 1967. Zur Kenntnis der Gattungen Reinholdella, Garantella und Epistomina (Foraminfera). Palaeontographica A, 127:103-108.

Renz, O., Imlay, R., Lancelot Y., and Ryan, W. B. F., 1975. Ammonite-rich Oxfordian limestones from the base of the continental slope, off Northwest Africa. Eclogae Geol. Helv., 68(2):431-448.

Schafer, C. T., and Carter, L., 1981. Bathyal zone benthic Foraminiferal genera off northeast Newfoundland. J. Foraminiferal Res., 11(4):296-313.

Sclater, J. G., Hellinger, S., and Tapscot, C., 1977. The paleobathymetry of the Atlantic Ocean from the Jurassic to the Present. $J$. Geol., 85(5):509-552.

Scott, D., Gradstein, F., Schafer, C., Miller, A., and Williamson, M., in press. The Recent as a key to the Past: does it apply to agglutinated foraminiferal assemblages? Proc. First Workshop Arenaceous Foraminifera, Amsterdam 1981.

Sliter, W. V., 1980. Mesozoic foraminifers and deep-sea benthic environments from Deep Sea Drilling Project Sites 415 and 416, eastern North Atlantic. In Lancelot, Y., Winterer, E. L., et al. Init. Repts. DSDP, 50: Washington (U.S. Govt. Printing Office), 353-427.

Veevers, J. J., Heirtzler, J. R., et al., 1974. Init. Repts. DSDP, 27: Washington (U.S. Govt. Printing Office).

Wall, J. H., 1960. Jurassic microfaunas from Saskatchewan. Dept. of Mineral Res. Prov. of Saskatchewan, Rep. No. 53, pp. 1-229.

Wernli, R., 1971. Les Foraminifères du Dogger du Jura meridional (France). Arch. Sci. Soc. Phys. Hist. Nat. Geneve, 24(2):306-352.

Wernli, R., and Septfontaine, M., 1971. Micropaléontologie comparee du Dogger du Jura méridional (France) et des Préalpes Medianes Plastiques romandes (Suisse). Eclogae Geol. Helv., 64(3):437-458.

Date of Initial Receipt: September 20, 1982 


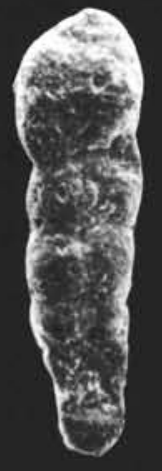

1

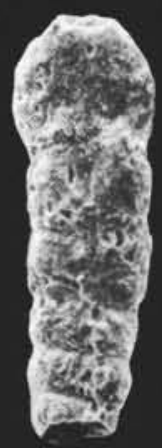

2

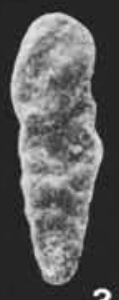

3

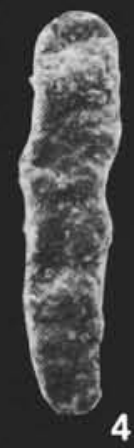

4

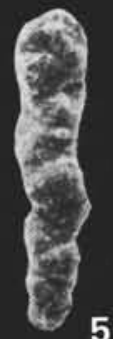

5
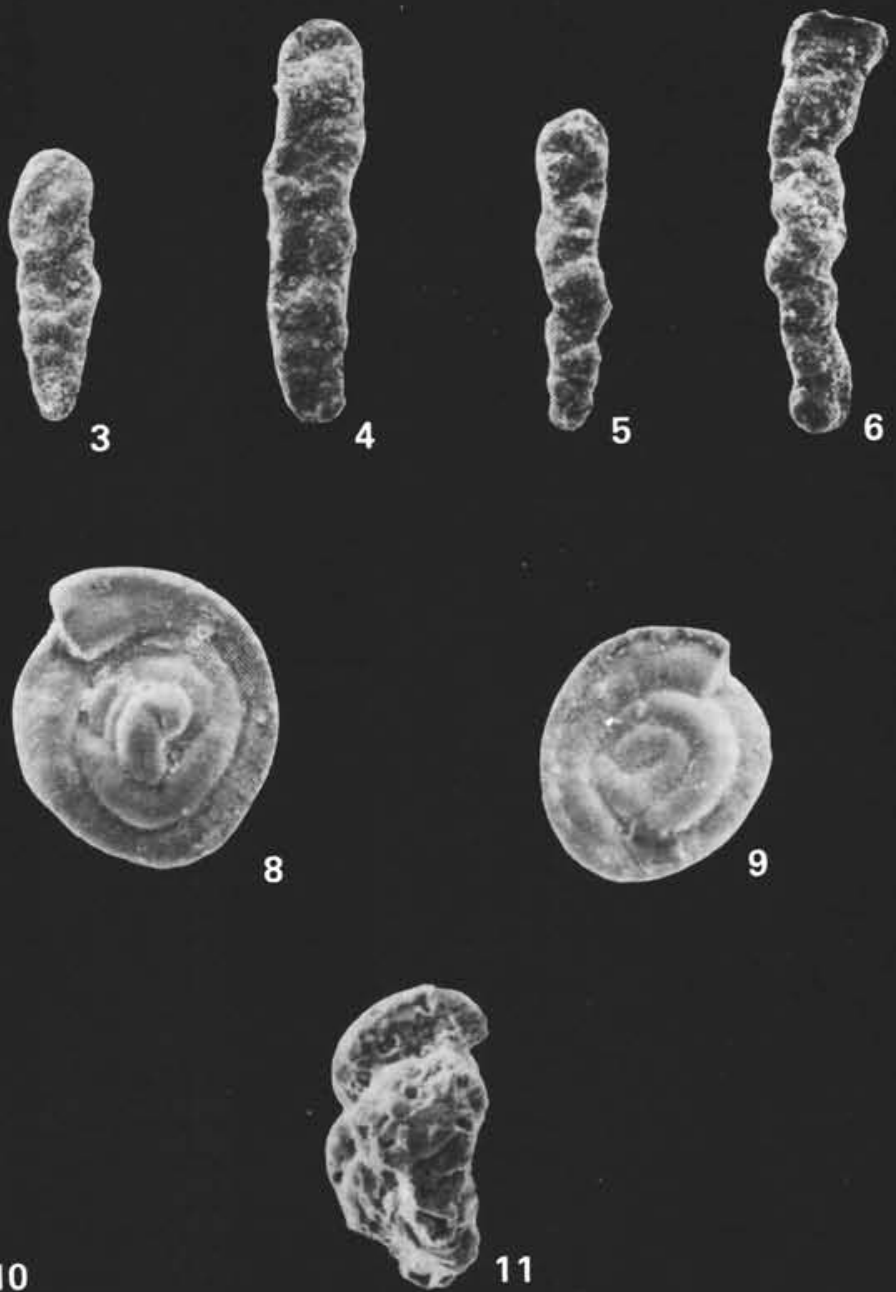

11
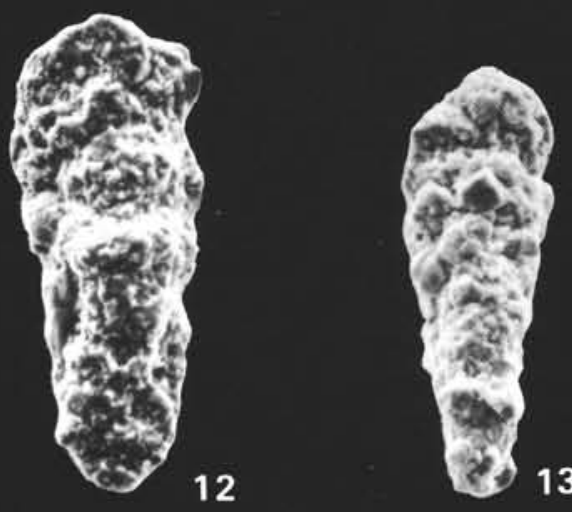

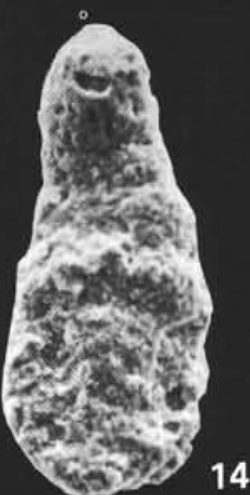

14

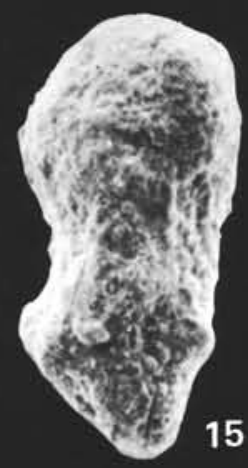

15

Plate 1. Middle-Late Jurassic, DSDP Hole 534A. 1. Bigenerina jurassica (Hauesler). Sample 534A-91-1, 20-21 cm. (Magnification $\times 90$.) 2. Bigenerina jurassica (Hauesler). Sample 534A-127-1, 59-62 cm. ( $\times 95$.$) 3. Bigenerina jurassica (Hauesler). Sample 534A-91-1, 20-21 cm.$ $(\times 100$.) 4. Bigenerina arcuata Haeusler. Sample $534 \mathrm{~A}-105-2,67-68 \mathrm{~cm} .(\times 100$.$) 5. Bigenerina arcuata Haeusler. Sample 534A-105-2, 67-68$ $\mathrm{cm} .(\times 100$.) 6. Bigenerina arcuata Haeusler. Sample 534A-105-2, 67-68 cm. $(\times 95) \quad$.7 . Glomospirella gaultina (Berthelin). Sample 534A$113-1,24-26 \mathrm{~cm} .(\times 120$.$) 8. Glomospirella gaultina (Berthelin). Sample 534A-79-3, 77-78 cm. ( \times 120$.) 9. Glomospirella gaultina (Berthelin). Sample 534A-94,CC. $(\times 120$.) 10-11. Trochammina quinqueloba Geroch. Sample 534A-94-1, 30-32 cm. $(\times 190) \quad 12$. Textularia hauesleri Kaptarenko Chernoussova. Sample 534A-126-4, 56-58 cm. $(\times 250$.$) 13. Textularia hauesleri Kaptarenko Chernoussova. Sample$ $534 \mathrm{~A}-126-4,56-58 \mathrm{~cm}$. $(\times 225$.) 14. Spiroplectammina helvetojurassica Kubler and Zwingli. Sample $534 \mathrm{~A}-93-3,6-7 \mathrm{~cm} .(\times 105)$. 15. Gaudryina heersumensis Lutze. Sample 534A-110,CC $(15 \mathrm{~cm}) .(\times 185$. 

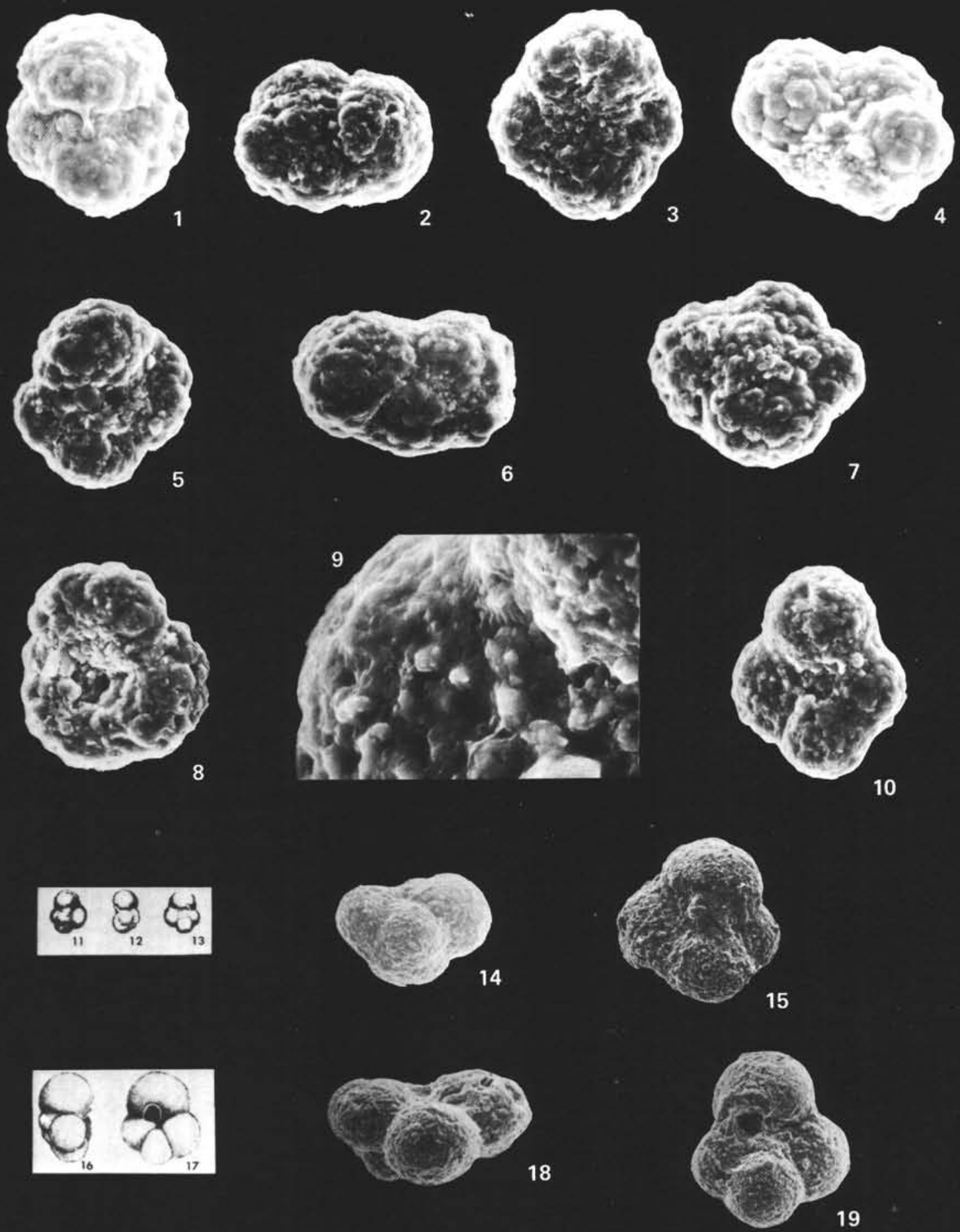

Plate 2. Jurassic planktonic foraminifers, DSDP Hole 534A. 1-2. Globuligerina aff. oxfordiana (Grigelis). Sample 534A-110,CC. (1) $\times 460$.

(2) $\times 420$. 3-4. Globuligerina aff. oxfordiana (Grigelis). Sample 534A-110,CC. (1) $\times 420$. (2) $\times 550$. (Note conspicuous coating with nannofossil tests.) 5. Globuligerina aff. oxfordiana Grigelis. Sample 534A-110,CC. $(\times 420$.) 6. Globuligerina aff. oxfordiana (Grigelis). Sample 534A-110,CC. $(\times 440$.$) 7. Globuligerina aff. oxfordiana (Grigelis). Sample 534A-110,CC. (\times 500$.$) 8. Globuligerina aff. oxfordiana (Grige-$ lis). Sample 534A-110,CC. $(\times 520$.) 9-10. Globuligerina aff. oxfordiana (Grigelis). Sample 534A-110,CC. $(9) \times 1600,(10) \times 470$. (The enlarged umbilical region in Fig. 9 shows several generations of pustules and fine wall perforation.) 11-13. Globuligerina oxfordiana (Grigelis) 1958. (Holotype, Oxfordian, Lituanian SSR, $\times 40$.) 14-15. Globuligerina oxfordiana (Grigelis), Reinholdella crebara var. Zone-Epistomina mosquensis Zone, Callovian-Oxfordian (Bittern M-62 well, swc 5380', Grand Banks; $\times 140$; note reticulate ridges pattern, as in Caucasella hoterivica (Subbotina), and "Kummerform" wall protrusion over the aperture.) 16-17. Globuligerina oxfordiana (Grigelis), specimen illustrated by Bignot and Guyader, 1966, Mariae Zone, early Oxfordian, northwestern France, $\times 105.18-19$. Globuligerina oxfordiana Grigelis, Hauffianum Zone, late Oxfordian, Montejunto, Portugal, $\times 180$. (Note loop-shaped aperture, as in Fig. 17.) 


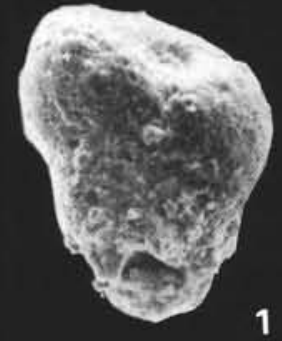

1

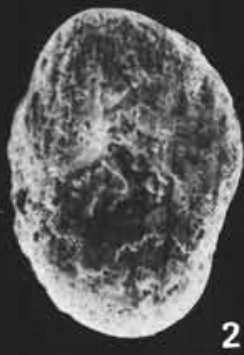

2
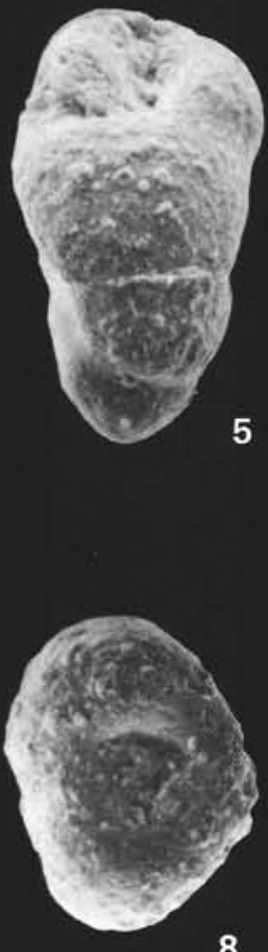

8

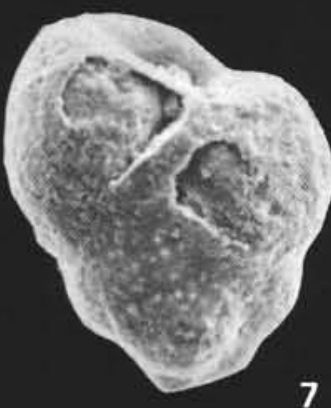

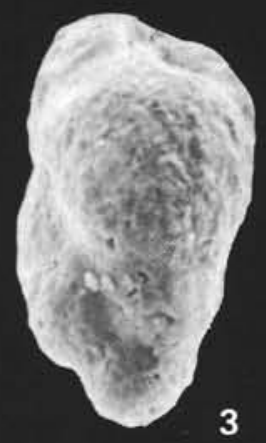

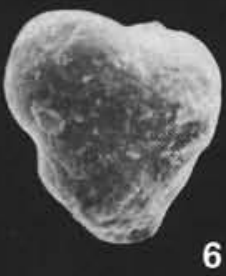

6

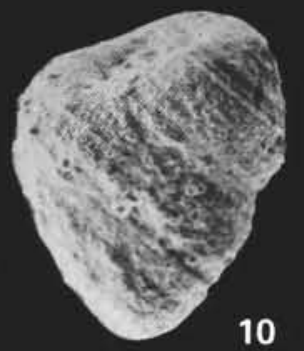

10

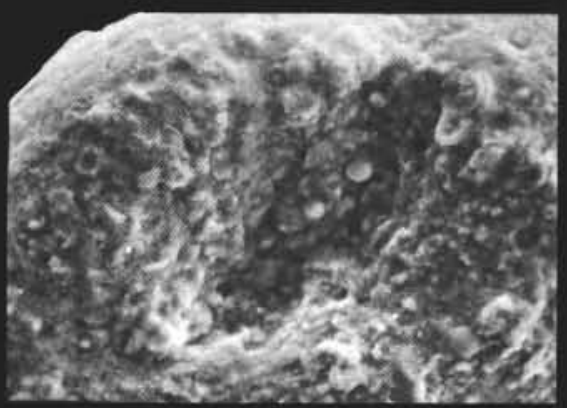

11

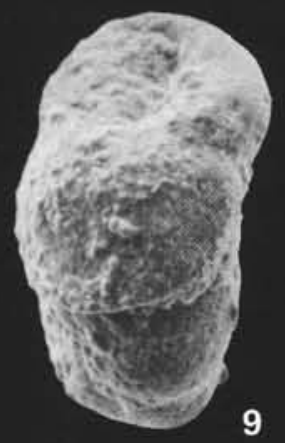

9

Plate 3. Middle-Late Jurassic, DSDP Hole 534A. 1-2. Neobulimina atlantica n. sp. holotype. Sample 534A-101-4, 93-95 cm. ( $\times 170$.) 3. Neobulimina atlantica $\mathrm{n}$. sp. paratype. Sample 534A-101-4, 93-95 cm. $(\times 180$.) 3. Neobulimina atlantica $\mathrm{n}$. sp. paratype. Sample 534A-101-4, 93-95 cm. 4-5. Neobulimina atlantica n. sp. paratype. Sample 534A-101-4, $93-95 \mathrm{~cm} .(\times 270$ or $\times 260$. $)$ 6. Neobulimina atlantica n. sp. paratype. Sample 534A-99-3, 77-78 cm. $(\times 190$.) 7. Neobulimina atlantica $\mathrm{n}$. sp. paratype. Sample $534 \mathrm{~A}-99-3,77-79 \mathrm{~cm}$. $(\times 215$.) 8. Neobulimina atlantica $\mathrm{n}$. sp. paratype. Sample 534A-99-3, 77-78 cm. $(\times 190$. $) \quad$ 9. Neobulimina atlantica $\mathrm{n}$. sp. paratype. Sample 534A-99-3, 77-78 cm. ( $\times 190$.) 10-12. Neobulimina atlantica n. sp. paratype. Sample 534A-99-3, 77-78 cm. (Fig. 11 is an enlargement of the apertural features; $\times 140, \times 380$, and $\times 190$.) 


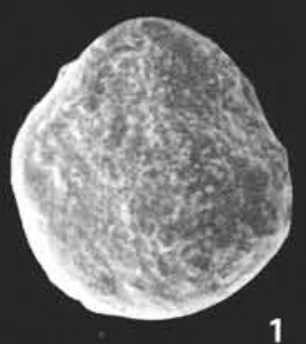

1

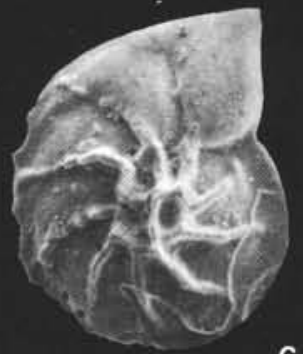

6

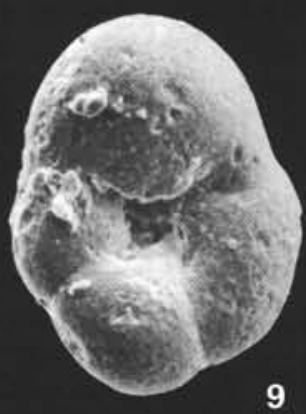

9

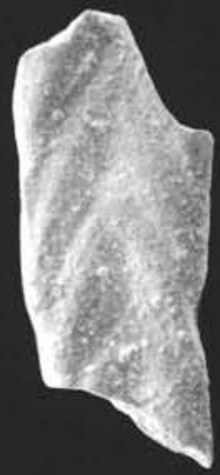

14

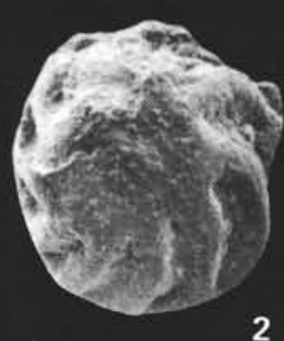

2

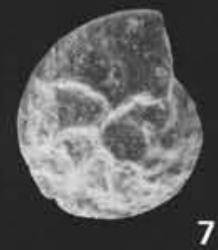

5
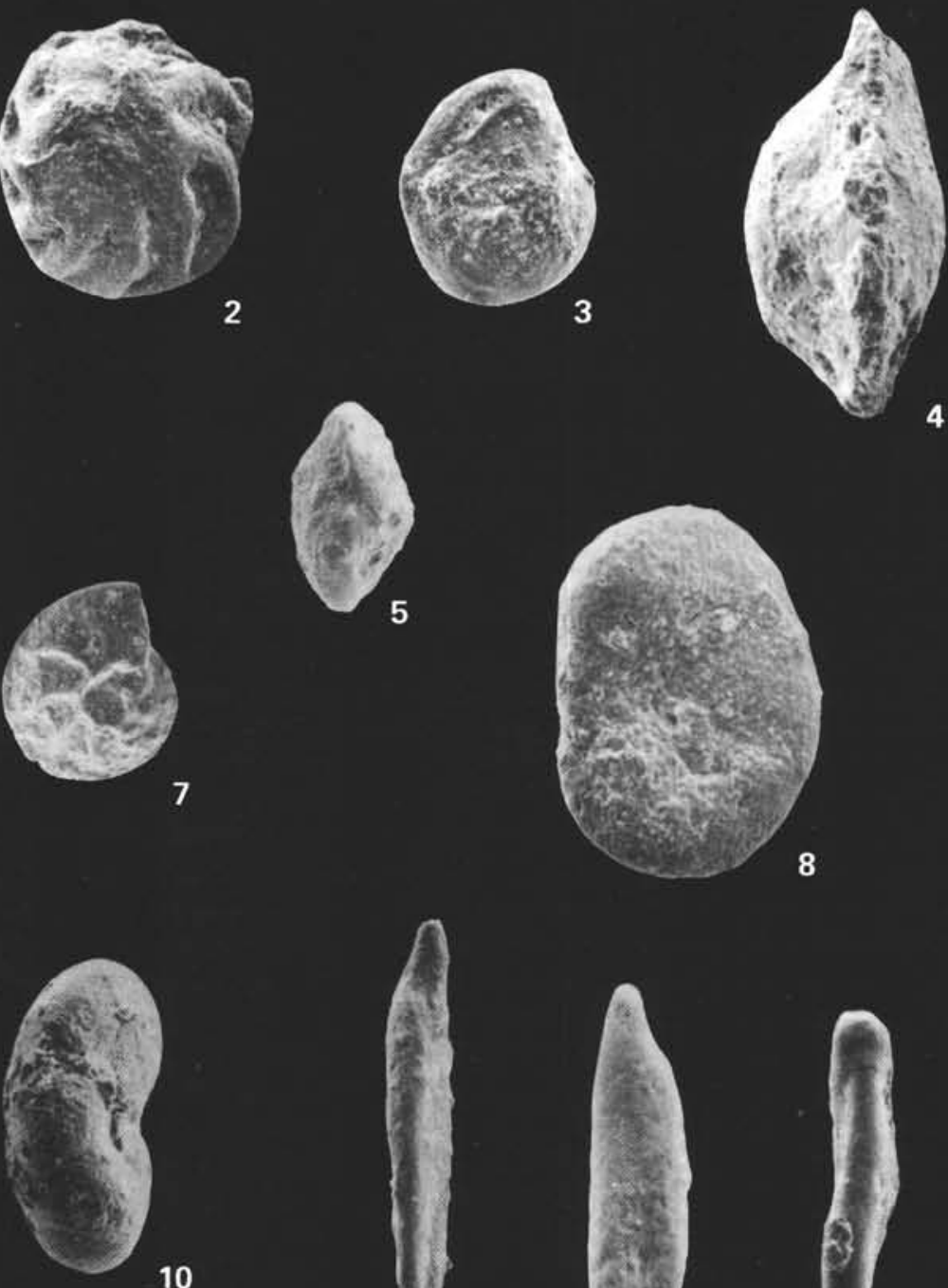

10
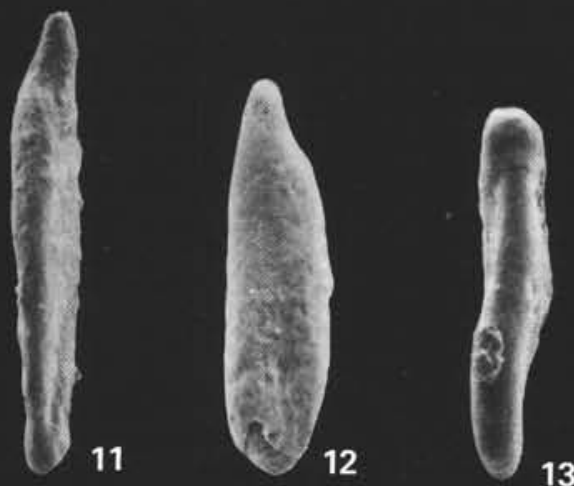

13

Plate 4. Middle-Late Jurassic, DSDP Hole 534A. 1. Epistomina aff. uhligi Mjatliuk. Sample 534A-99-3, 77-78 cm. ( $\times 90$.) 2. Epistomina aff. uhligi Mjatliuk. Sample 534A-102-5, 75-77 cm. ( $\times 45$.) 3. Epistomina aff. uhligi Mjatliuk. Sample 534A-99-3, 77-78 cm. ( $\times 90$.) 4. Epistomina aff. uhligi Mjatliuk. Sample 534A-102-5, 75-77 cm. $(\times 80$.$) 5. Epistomina aff. uhligi Mjatliuk. Sample 534 \mathrm{~A}-99-3,77-78 \mathrm{~cm}$. ( $\times 90$.) 6. Lenticulina quenstedti (Guembel). Sample 102-2, 64-66 cm. $(\times 80$.) 7. Lenticulina quenstedti (Guembel). Sample 534A-99-3, 77-78 $\mathrm{cm} .(\times 80$.$) 8. Conorboides paraspis (Schwager). Sample 534A-110,CC (15 \mathrm{~cm}) .(\times 165$.$) 9-10. Conorbina sp. Sample 534A-110,CC (15 \mathrm{~cm})$. $(\times 175$ and $\times 135$.) 11. Ophthalmidium milioliniformis (Paalzow), Sample 534A-104-3, 38-39 cm. $(\times 120$.) 12. Ophthalmidium milioliniformis (Paalzow). Sample 534A-104-3, 38-39 cm. ( $\times 120$.) 13. Ophthalmidium milioliniformis (Paalzow). Sample 534A-104-3, 38-39 cm. $(\times 120$.) 14. Palmula subparallela (Wisniowski). Sample $534 \mathrm{~A}-113-1,24-26 \mathrm{~cm}(\times 100$.) 15. Palmula subparallela (Wisniowski). Sample 534A-113-1, 24-26 cm. ( $\times 100$.) 16. Palmula subparallela (Wisniowski). Sample 534A-113-1, 24-26 cm. $(\times 100$.) 17. Frondicularia nikitini Uhlig. Sample 534A-99-3, 77-78 cm. $(\times 100$.) 18. Frondicularia franconica Guembel. Sample 534A-126-4, 56-58 cm. $(\times 190$.) 